\title{
A Comprehensive Study on the Recent Progress and Trends in Development of Small Hydropower Projects
}

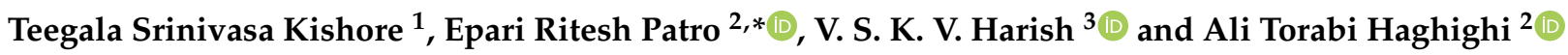 \\ 1 Electrical \& Electronics Engineering, GMR Institute of Technology, Rajam 532127, India; \\ srinivasakishoret@gmail.com or kishore.ts@gmrit.edu.in \\ 2 Water, Energy and Environmental Engineering, University of Oulu, 90014 Oulu, Finland; \\ ali.torabihaghighi@oulu.fi \\ 3 Department of Electrical Engineering, School of Technology, Pandit Deendayal Energy University \\ Gandhinagar, Gujarat 382481, India; vskvharish@ieee.org \\ * Correspondence: ritesh.patro@oulu.fi
}

Citation: Kishore, T.S.; Patro, E.R.; Harish, V.S.K.V.; Haghighi, A.T. A Comprehensive Study on the Recent Progress and Trends in Development of Small Hydropower Projects. Energies 2021, 14, 2882. https:// doi.org/10.3390/en14102882

Academic Editor: Chirag Trivedi

Received: 30 March 2021

Accepted: 13 May 2021

Published: 17 May 2021

Publisher's Note: MDPI stays neutral with regard to jurisdictional claims in published maps and institutional affiliations.

Copyright: (c) 2021 by the authors. Licensee MDPI, Basel, Switzerland. This article is an open access article distributed under the terms and conditions of the Creative Commons Attribution (CC BY) license (https:// creativecommons.org/licenses/by/ $4.0 /)$.

\begin{abstract}
In terms of fuel resource, hydropower possesses a prominent advantage over any other large power plants which burn fossil fuels to generate electricity. Moreover, due to the abundance in resource availability (as a domestic source in small streams and rivers), small hydropower (SHP) plants are showing prominence all over the world. SHP plants have led to improved access to electricity usage in under-developed and developing nations, thereby contributing to sustainable development goals and social empowerment. SHP, as a technology, is regarded as the largest density renewable resource with high adaptability, and low investment costs. The primary objective of the paper is to study and analyze recent developments in SHP technologies with reporting statistical figures in terms of installed capacity and MW potential in several parts of the world. Methodologies adopted by researchers to conduct techno-economic analysis of SHP projects are reviewed. Various costs involved in conducting pre-feasibility studies—such as constructing, maintaining, and sustainably operating SHP projects-are studied. The results of the study indicate cost and regulatory issues are the major factors affecting the growth of the small hydropower sector in many nations. Major impediments to construction, development and deployment of SHP projects, mutually existing among the nations worldwide, are also reported. Technical hindrances include non-availability of the grid and very limited accessibility to SHP sites, emissions due to storage of water, disruptive technologies with limited manpower and non-technical hindrances include discouragement from local bodies and groups, lack of suitable and precise pathways to accomplish SHP goals of a nation, lack of incentives for encouraging private players to invest in SHP projects, complex approval processes, and many more.
\end{abstract}

Keywords: renewable energy; techno-economic analysis; small hydropower (SHP); sustainability

\section{Introduction}

Global energy demand is rising exponentially due to growth in the economy and population, especially in developing nations. This rise in demand is viewed as a positive indicator for a rise in the economy but also poses new challenges such as energy security, global warming, etc. A rising economy means more consumers which require more resources to generate energy and since most of the energy is being produced by fossil fuels, it leads to more greenhouse gas emissions, especially carbon dioxide, which is a major contributing factor to global warming. On the other hand, unacceptably high numbers of the population are still lacking electricity access. In this scenario, the generation, transmission, distribution, and consumption of energy needs transformation for a sustainable energy future. This is essential to increase the living standards, provide access to contemporary energy services, use energy more efficiently, safeguard the environment worldwide, and ensure a reliable energy supply. 
Renewable energy sources play a greater part, accounting for about $26 \%$ of the global power generated in 2019 [1]. Power generation from renewable sources accounted for an estimated $18.1 \%$ of total final energy consumption (TFEC) [2]. An addition of 181 gigawatts (GW) of renewable power to the existing generation and the grid integration of large quantities of this power, which is fluctuating in nature, is found to be escalating globally in 2018. Global power generating capacity from renewable energy sources was estimated to be around $2.378 \mathrm{GW}$ in the year 2018 [3]. For the fourth successive year, the capacity addition of renewable energy sources was higher than the combined addition of nuclear and fossil fuel-based power generation. The share of solar photovoltaic (SPV) power generation systems in this addition was estimated to be $100 \mathrm{GW}$, which closely figures to be $55 \%$ of the total renewable capacity addition trailed by a $28 \%$ share of wind energy conversion systems (WECS), and 11\% hydropower [4]. Overall, power generation from renewable energy has accounted for $33 \%$ of the total installed power generating capacity globally and has earned recognition for itself on a global scale in mitigating climate change. In 2018, more than 90 nations had installed no less than $1 \mathrm{GW}$ of renewable energy generating capacity and 30 countries installed more than $10 \mathrm{GW}$ of renewable energy generating capacity. WECS and SPV further improved their segments and an increasing number of nations have no less than $20 \%$ renewable energy generation in their electricity mixes to meet their respective load demand [5]. Table 1 shows the installed capacity in GW for various renewable energy technologies worldwide.

Table 1. Installed capacity in GW worldwide until 2019 [5].

\begin{tabular}{cc}
\hline Renewable Energy & Installed Capacity (GW) \\
\hline Hydropower & 1132 \\
Small Hydropower & 170 \\
WECS & 591 \\
SPV & 505 \\
Bio-energy & 130 \\
Geothermal energy & 13.3 \\
Solar thermal energy & 505 \\
Ocean energy & 0.5 \\
\hline
\end{tabular}

The overall development was focused on the power sector, the obvious reasons being, renewable energy is progressively cost-competitive related to conventional coalfired power generation [6]. Acceptance of these renewable sources was motivated by goals and firm policies made by respective policy makers across nations. This led to the creation of decarbonization paths and agendas by many states, aiming for added ambitious goals beyond their national equals. Third world nations were persistent in escalating their distribution of renewable energy sources and dispersed generation using replenishable energy sources aided electricity access to remote households by spreading energy resources to areas where the scope for extending the conventional electricity grid is uneconomical or technically infeasible [7]. It is found that the overall investment in the renewable sector has seen a downtrend recently; however, developing nations and emerging economies share was over half of the total investment [8]. The sector was able to provide total employment to 11 million people globally. Prospects endure developing for augmented use of electricity generated through renewable energy sources in enduse sectors. Grid integration of the renewable energy sector has played a key part in attracting the consideration of governments and policy makers in framing future road maps. Promising technologies—such as battery energy storage systems, electric vehicles, etc.- - saw a surge in market growth; however, the development of renewable energy sector needs to have a holistic growth with a motto to develop strategies to openly support the interconnection of all stakeholders in the renewable sector-i.e., power, heating and cooling, and transportation - which is still deficient [5].

In this context, the role of small hydropower (SHP) and its status of development needs to be evaluated, to have a mature technology that serves an important role in the 
energy transition. Accordingly, the objectives of this paper are (a) to understand the current trends and challenges of the development of SHP worldwide, (b) to analyze the profitability and sustainability of SHP, and (c) to explore possible approaches and solutions to enhance its sustainable development.

\section{Hydropower and SDGs}

Hydropower facilitates various benefits such as supervision and control of freshwater usage, mitigation of adverse environmental effects by slowing, stabilizing or reversing the climate change by reducing greenhouse gas emissions, anticipating and preparing for the possible adverse effects caused by climate change, and thus able to decrease the accompanying health problems [9]. Hydropower aids in improving the affordable services, guaranteed energy delivery under normal and adverse conditions, clean and improved efficient energy goal (SDG 7), clean water and sanitization goal (SDG 6), strong infrastructure and innovation goal (SDG 9), and goal for action against climate change (SDG 13). The need for clean and sustainable energy sources raises severe concerns on account of climate change for both emerging and advanced nations. Hydropower, which is the least costly renewable energy in terms of technology and resource, prevails at the epicentre of global efforts to combat climate change.

Hydropower is a renewable, economical, non-polluting, and environmentally benign source of energy. Significant infrastructural developments are being incorporated to improve the performance and efficiency of hydropower plants. Constructing a super long headrace tunnel $[10,11]$, advanced governor control through the development of a chaotic turbine regulating system [12], and integration of hydropower with large solar PV and wind farms [13] are few such developments. Hydropower plants also assist in catering to the dynamic load changes and resultant frequency variations [14]. Hydropower is best known for its stability in fluctuating market conditions, can withstand heavy competition from industry and is a promising technology for the growing demand for energy storage in the form of pumped storage plants [15]. An expected $20 \mathrm{GW}$ capacity addition was done in 2018 , increasing the aggregate installed capacity to 1132 GW globally with a corresponding estimated energy generation of 4210 TWh considering the fluctuating nature of hydropower generation owing to changing weather patterns and local geographical conditions. Hydropower plants possess the innate capability of providing the fastest response to load variations during operation, thereby augmenting the overall power network reliability. Hydropower plants, especially pumped storage plants, are considered a superlative option for handling the peak demand. The cost of hydropower generation is not only independent of inflation but also subsides with time and support in starting up new opportunities for the development of far-off and isolated areas. Keeping in view the growing need for integration of various renewable energy sources, as well as interconnecting large scales of renewable energy sources with grid, hydropower is gaining increased attention as it can offer effective integration with other renewable sources, especially wind and solar, based on local conditions and due to its synergy.

Hydropower plants possess extensive operating life prolonging over 50 years and setting up of these plants support in preserving rare fossil fuels. However, more than half of all hydropower facilities worldwide have either already undergone or will soon require upgrades and modernization. Even though hydropower plants are recognized as the most economical and sought-after resource of electricity, their share has been diminishing progressively [16]. The best hydro-thermal mix should be in the ratio of 40:60, to avoid back down of the thermal station during off-peak periods [17]. The capacity of the thermal plants cannot be fully utilized resulting in a loss of about $4-5 \%$ in the plant load factor. A $5 \%$ increase in the share of hydropower in the hydro-thermal mix requires an estimated 10 GW of hydropower capacity addition $[1,18]$. Table S1 in Supplementary S1 represents the global hydropower statistics region wise. It can be observed from Table S1 that China is the global leader in the production of electricity from hydropower followed by Canada, Brazil, the USA, and the Russian Federation. However, the percentage of hydropower share 
regarding the total installed capacity is highest for Brazil followed by Canada, Russian Federation, China, and the USA. It can also be observed that twelve countries spread around the world have hydropower capacity of more than $90 \%$ regarding their installed capacities. It is to be noted that six out of these twelve nations are from Africa, which shows the significant development that can be achieved in terms of economy, community and social development through electricity generation from hydropower [19].

Under these circumstances, power planners worldwide are giving special attention to the accelerated development of hydropower as an important energy resource for ensuring energy security. However, large hydropower plants suffer from inherent drawbacks such as high capital investment, long gestation period, submergence of large fertile and forest areas, and rehabilitation of population etc. from the sites [9]. It is in this scenario small hydropower (SHP) was evolved because of political and environmental implications on the development of large hydro power. The technology involved in SHP is extremely robust with an average lifetime of 50 years and requires little maintenance. Of all the renewable energy technologies available, SHP represents the highest density renewable resource. SHP occupies a leading position globally in generating power from renewable energy sources. SHP plants have the advantages of smaller gestation periods, negligible submergence and resettlement, and minimal problems related to the environment and ecology [20]. Small hydropower (SHP) is a central part of a wider approach to encourage all-inclusive growth while simultaneously reducing greenhouse gas releases and stimulating better energy independence.

\subsection{Importance of SHP as a Renewable Energy Source}

SHP is native renewable energy, which is equally dependable and cost-effective compared with other substitutes with the same capacity. SHP delivers cost-effective, societal, and ecological benefits, for instance growing industrial competitiveness, generating employment, etc. It has vast unexploited potential in several regions and can be proficiently designed, operated, and maintained in the vicinity. SHP has relatively lesser energy generation costs as related to other off-grid technology. SHP design is highly flexible and adaptable to several topographical conditions. SHP has massively augmented rural electrification, enhanced living and production conditions, reinvigorated the development of the economy in rural areas, lessened poverty, and resulted in decreased carbon emissions. SHP is preferred by emerging nations as it has huge capability and its technology is efficient as well as techno-economically feasible. There exists no typical classification concerning the capacity of 'small' and 'large' hydropower and so, the definition of SHP varies from nation to nation. The portrayal of SHP schemes of any given nation is significant since it can govern which hydropower plants are covered by sustenance policies and ecological regulations conferring to their sizes [20]. Table S1 shows the country-wise definition of SHP along with corresponding installed and potential capacities. Most of the countries adopted a capacity of $10 \mathrm{MW}$ for defining SHP. Most of the studies made by various national and international agencies also rely on this definition worldwide for undertaking SHP studies and research. Hence, in this research review, concurrent with the SHP stakeholders, $10 \mathrm{MW}$ is benchmarked as the defined capacity for SHP for analysis purposes.

The SHP international market is divided into two broad categories based on capacity, less than $1 \mathrm{MW}$ and between 1-10 MW. SHP plants with a power generation capacity of $100 \mathrm{~kW}$ to $1 \mathrm{MW}$ are termed mini-hydro plants and are mostly suitable for standalone and microgrid operations. SHP plants with a power generation capacity between $5 \mathrm{~kW}$ to $100 \mathrm{~kW}$ are named as micro-hydro plants and are suitable for providing power to isolated loads such as small communities or industry in rural areas which are not gridconnected. SHP plants that possess power generation capacity of less than $5 \mathrm{~kW}$ are known as pico-hydro plants, commonly employed for off-grid applications in remote areas. $80 \%$ of total SHP plant capacities lie within 1-10 MW and these are commonly constructed and extensively functional on small rivers or water reservoirs, which found to be highly efficient in meeting the peak power demand posed on the grid. The capital cost, operation, 
and maintenance cost and the levelized cost of electricity of 1-10 MW SHP plants are lower as compared to plants below $1 \mathrm{MW}$ capacity owing to an increased head and installed power generation capacity of the former and also aiding significant market growth in this range [21].

\section{Current Trends, Challenges, and Recommendations}

The energy sector is among the most vital sectors facing economic, environmental, and development issues. A key factor to meet electricity consumption globally is to generate clean energy and deploy new facilities. Concerns over climate change and greenhouse gas (GHG) emissions by conventional fossil fuels are on the rise and there is an urgent need for a paradigm shift to green and environmentally friendly sources of energy. Such situations focus on the prominence of diversification and conventional energy independence. As of 2018, the worldwide installed capacity of hydropower amounts to 1.3 TW and generation of 4.2 TWh of energy [22]. On the contrary, hydropower plants necessitate acceptable design and planning to counter hostile effects on the environment and safeguard sustainable operation. SHP is an established and adaptable technology, necessary for providing access to environmentally friendly energy in emerging nations, particularly in rural areas. With the development of SHP, several nations have, by now, taken initiative or are starting to take initiative to lessen poverty and increase access to energy. SHP aids the advanced countries to realize their targets for progressing renewable energy usage and plummeting greenhouse gas emissions [23]. In this section, current trends in the development of the small hydro sector, challenges posed to the industry, and possible solutions for mitigation of these challenges have been discussed.

\subsection{Current Trends Worldwide}

Globally, SHP represents $1.5 \%$ of total electricity installed capacity, $4.5 \%$ of renewable energy installed capacity, and 7.5\% of hydropower capacity. Figure 1 shows the year-wise growth in SHP installed capacity and existing potential worldwide. Asia-Pacific has a major share in the SHP market worldwide. In the past decade, China was able to lead the regional SHP market segment as the Chinese administration continuously poured in the required inputs to the erection of new SHP plants. These constructions were primarily intended at providing energy for hilly areas in association with small-scale water conservation schemes. Regional statistics show that the Pacific region accounts for the least share of SHP installed capacity whereas Asia has the maximum SHP installed capacity. 65\% of the global SHP installed capacity is present together in Asia and the Pacific region. The installed SHP capacity in Japan and India is comparatively less with $35 \%$ and $18 \%$ of their potential capacities. India is anticipated to observe the development of SHP owing to the measures taken by the government such as Rajiv Gandhi Grameen Vidyutikaran Yojana and Small Hydro Power Program by the Ministry of New and Renewable Energy. Rajiv Gandhi Grameen Vidyutikaran Yojana in India is meant for the electrification of rural areas and encourages the use of alternative and clean energy sources like SHP, solar, etc. for mini-grid or off-grid applications. India aims at developing SHP projects in public, private or publicprivate mode while giving the same importance to grid-tied and decentralized projects. Several SHP projects had been operational or being constructed in remote and isolated areas, mainly in the Himalayan \& Western Ghat region of India. Although these projects are established by different state government departments accountable for green energy, the operation and maintenance of these projects are usually carried out by entrepreneurs or by the local communities' /Gram Panchayat/tea garden owners' contributions in India [24]. 


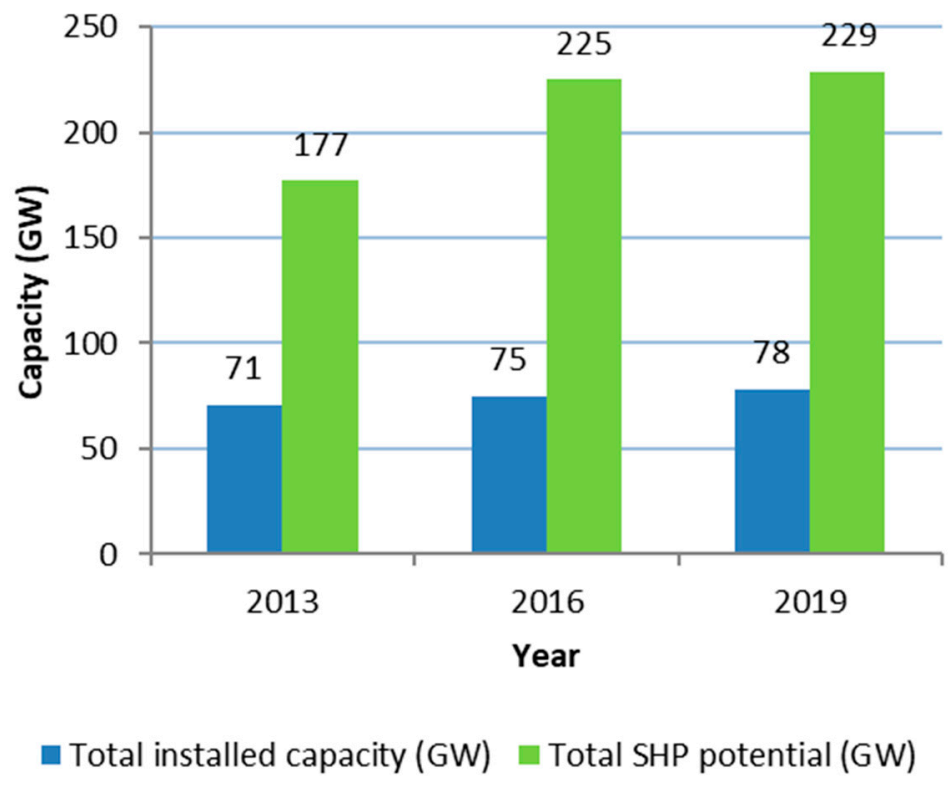

Figure 1. Worldwide SHP installed vs. potential capacity [24].

Europe is anticipated to observe considerable growth in SHP as an outcome of encouraging government rules. The Renewable Energy Directive of the European Union states that all affiliate countries must increase the stake of renewable energy to $20 \%$. European SHP Association was established to outline a clear and dependable Stream Map for the SHP division in Europe, pertinent to the views of the EU Energy and Climate Packet guidelines established on the existent condition of the SHP division at present and the commendations for the future. Europe has a considerable deployment of SHP, with an installed capacity of more than $45 \%$ of the overall estimated potential. Brazil has a huge undeveloped potential of SHP, around 30\%. USA harnessed more than $50 \%$ of its SHP potential; however, the growth in installed capacity was observed to be constant in the past few years and is anticipated to exploit the available SHP potential soon. The 2013 USA Hydropower Regulatory Efficiency Act aids in setting-up SHP up to 50 MW. Currently, in the USA, quite a lot of renovation and upgradation of SHP projects are ongoing [19].

Of the available SHP potential, Africa and the Middle East had developed less than $5 \%$ making them the nations with the least installed capacity. In 2014, the United Nations Development Program was executing a scheme to encourage investment in SHP centred mini-grids aimed at countryside electrification in the Democratic Republic of Congo, and this scheme was sponsored by the GEF Trust Fund. South Africa has five times more untapped SHP potential as compared to the currently installed SHP capacity. SHP plants in South Africa are operated in standalone or gird tied modes, can be a standalone source or a hybrid blend along with other renewable energy sources. SHP has a huge scope of unexplored competencies; however, less than $40 \%$ of its entire market potential was exploited globally. As discussed in Section 2.1, the above analysis was presented keeping in view the capacity definition of SHP as $10 \mathrm{MW}$. Table 2 represents the global data regarding region-wise SHP potential, developed capacity, and potential yet to be developed [19]. 
Table 2. Global SHP statistics [19].

\begin{tabular}{cccc}
\hline Region & Potential (MW) & Developed (MW) & Remaining (MW) \\
\hline WORLD & 229,142 & 78,046 & 151,096 \\
Eastern Asia & 75,437 & 45,723 & 29,714 \\
Central Asia & 34,358 & 266 & 34,092 \\
South America & 28,483 & 806 & 27,677 \\
South East Asia & 16,361 & 850 & 15,511 \\
Southern Europe & 14,746 & 6881 & 7865 \\
North America & 11,879 & 4734 & 7145 \\
Northern Europe & 10,805 & 4401 & 6404 \\
Western Asia & 7916 & 3533 & 4383 \\
Western Europe & 7635 & 6514 & 1121 \\
Eastern Africa & 6833 & 276 & 6557 \\
Eastren Europe & 4370 & 1903 & 2467 \\
Southern Aisa & 4203 & 697 & 3506 \\
Middle Africa & 1856 & 114 & 1742 \\
Central America & 1202 & 524 & 678 \\
Australia and New Zealand & 795 & 327 & 468 \\
Western Africa & 610 & 44 & 566 \\
Northern Africa & 520 & 112 & 408 \\
Southern Africa & 422 & 50 & 372 \\
PICT's & 413 & 114 & 299 \\
Latin America and Carribean & 297 & 177 & 120 \\
\hline
\end{tabular}

\subsection{Major Challenges for the Development of SHP}

According to Access to Energy 2020.940 million individuals are yet to gain access to electrical energy while 3 billion are striving to access clean fuel to overcome their several energy requirements. United Nations assessed that amongst that electrical energy access, 1 billion individuals suffer from problems associated with have inferior electrical energy quality or provided access irregularly from undependable power grid networks. Electrification is a vital criterion for all-inclusive growth; however, the truth is that hundreds of millions of individuals continue to be surrounded by a cycle of electricity scarcity. Although unproductive, several individuals depend on outdated energy sources, even though it was observed that the production and use of such sources are harmful to the wellbeing of individuals and the environment. SHP is an established modest technology with renewable nature, which can enhance electrical energy access in rural parts and remain a part of the way out for communally comprehensive sustainable industrial development as per the obligation of the United Nations Industrial Development Organization (UNIDO) and Sustainable Development Goal (SDG) 7.1 to safeguard worldwide access to reasonable, dependable, and contemporary energy services by 2030. One of the foremost challenges of executing SHP projects is capital cost. Nevertheless, this drawback is balanced against the benefits that can be derived in the long term. SHP is a locally accessible renewable electrical energy source used for electrification and can operate in both off-grid and grid tied mode as well as in a non-polluting, effective and secure means. Apart from mobilizing the financial resources locally, it ensures a high energy tariff payback ratio. These monetary benefits contribute to the long term socio-economic expansion of inhabitants who are presently a minority cluster, distributed and geologically isolated, battling their defenseless position with independent electrical energy production and a robust micro-grid system [25].

Several nations, together with numerous small island states, depend on diesel for electrical energy production. This makes them vulnerable to rising gasoline costs and increasing trade shortages. The transformation from conventional fossil fuel-based energy production methods to renewable energy (SHP) provides better energy independence and economic solidity, in addition to aiding the mitigation measures undertaken to combat climate change. Even in nations with 100\% electrification, SHP can aid in achieving renewable energy goals, energy divergence and energy independence. The main obstacles to SHP growth, mutually existing among the nations worldwide, are as follows [19]: 
(a) The lack of precise and up-to-date data regarding the potential of SHP is a common obstacle that is responsible for poor interest exhibited by the private sector in developing the SHP sector in emerging nations. Wherever they are made available, both in advanced and emerging nations, the data presented in reports on SHP potential is found to be based on obsolete studies and fail to accommodate for existing policy structures, technological advances, and the potential rising from the rehabilitation of old sites or the improvement of present waterways and dams.

(b) In several nations, the focus on renewable energy was mostly entrusted in solar and wind energy development neglecting other forms of renewables that have a good amount of exploitable potential. The policies and financial benefits proposed by governments were offered to keep in view solar and wind energy systems and most of these do not apply to other renewable energy sources, particularly SHP. In some nations more focus was paid to the development of large hydro power and this led to the opinion that SHP development can be associated with large hydro power development and need not be dealt with separately. SHP development even today is perceived as high risk by private investors, especially in emerging nations, even though they have medium- to long-term advantages that outweigh the primary disadvantage of large hydropower i.e., capital investment. As a result, SHP schemes in emerging nations are frequently realized through subsidies or soft loans from international financial institutions or advanced nations, which do not signify a sustainable financing model.

(c) Although several nations have renewable energy goals, comprising SHP specific goals, many still lack suitable and precise pathways to accomplish these goals which could be associated with plans for developing allied sectors for example water and environment.

(d) Several nations have not yet specifically developed any incentives for promoting renewable energy, SHP in particular. It is critical that incentives and subsidy policies should be custom-made to meet the specific needs of the SHP industry as well as the nation; otherwise, they may harm SHP development. In most of the emerging nations, the incentives came into force as part of electricity trading regulations or to promote all-inclusive renewable energy growth to meet the renewable energy targets.

(e) The development of SHP is highly dependent on indigenous technological skills and expertise as SHP are highly site-specific. The design, construction and operational aspects are to be aligned with the local geographic conditions existing at the site. All these aspects necessitate the development of indigenous technologies and skilled manpower which would otherwise increase the financial burden on the SHP sector in the form of imports, duties and taxes.

(f) As the majority of the potential SHP sites are situated in mountainous and forest areas which are less developed and remote regions, many situations account for the non-availability of the electricity grid. It is in the hands of the government to frame policies for the promotion of grid integration of SHP in the form of grid extension or financial support; otherwise, most of the exploitable potential remains untapped or becomes very expensive for the developer.

(g) In many advanced nations, new regulatory frameworks for protecting the environment posed several implications on potential SHP sites for their development which either require additional expenses, which make the projects financially unfeasible, or preclude the complete development.

(h) Most of the emerging nations adopt cumbrous and extensive administrative processing mechanism for granting the necessary approvals which spread across several departments, making the overall process costly and time-consuming which delays the implementation of the project and discourage developers.

(i) Although SHPs do not have a huge carbon footprint as compared to large hydro, the majority of the public, especially in remote areas of emerging nations, consider them detrimental to the environment. Awareness must be increased to enlighten the public 
on the numerous roles SHPs can play, starting from sustainable electricity generation, rural electrification, and all-inclusive growth.

(j) Adverse climate change affects every sector and SHP is not exceptional. Change in the ecology of the river systems disturbing the water flow patterns and levels affect the reliability of SHP schemes by increasing competition among the SHP sector with others such as the ones of water resources and management. Nevertheless, instead of discouraging the development of SHP owing to negative impacts, climate change necessitates the adoption of SHP, as well as other renewable energy technologies, for power generation immediately to mitigate the negative climate change effects, especially in emerging nations.

\subsection{Possible Solutions for Mitigation of Challenges}

Regardless of the growth in the renewable energy sector, energy efficiency and energy access, it is to be noted that the world is not heading in the right direction to meet the goals of the Paris Agreement or SDG 7. To reach these goals, the existing regulatory frameworks are not enough, and major reforms need to be brought in. Renewable energy sustenance strategies and goals were available in almost all nations globally where policy makers have the responsibility and prospects to design an efficient amalgamation of these strategies following the conditions prevailing locally. The strategies and measures continue to develop and acclimate due to the falling nature of renewable energy technologies at a significant rate. The implementation of renewable energy sustenance strategies is driven by the varied benefits of these energy sources which include better-quality public health resulting from reduced pollution, enhanced reliability and resilience, and the creation of new avenues for employment. However, renewable energy policy frameworks diverge significantly in scope and completeness, which is the main reason why most of the renewable energy targets stay far away from the desired mark which is essential to achieve global climate goals. By 2018, renewable energy goals were espoused by 169 nations at the country or state level. Fresh and revised goals have turned out to be progressively desirous, predominantly in the power sector, but no goals or very less importance was observed for transport, cooling and heating sectors, and also goals for transformation of energy economy-wide is highly difficult to find in the policies. State governments are in general the icebreakers in forming state-of-the-art and aspiring mechanisms, comprising 100\% renewable energy or power goals $[5,19]$.

Policy decision-makers are not only extending maximum support for integrating renewable energy but also encouraging integrating different sectors and deploying various enabling technologies. Strategies to integrate various renewable energy technologies were able to address the issues regarding supply and demand to further enhance the flexibility of the total system. However, this can only be achieved by focusing on integrating sectors, deploying technologies offering auxiliary grid services, or novel and evolving technologies such as battery storage. An evolving trend is strategies that help promote the combined installation of renewable energy sources and energy storage systems. Reforms in carbon pricing, taxes, and emission trading strategies can promote the installation of renewable energy sources to see that climate change goals are met. Even though such strategies are increasing, currently only $13 \%$ of global emissions are covered by them. The policies addressing the climate change mitigation and adaptation goals are providing direct and indirect support to various renewable energy technologies. In 2017, 46 carbon pricing initiatives are in force and a whopping 54 extra have been added to this list by the end of 2018. Out of these newly added 54 initiatives, 27 refer to emissions trading and 27 to carbon taxes. Significant change can be brought upon by policy makers in this scenario for the development of the SHP sector and in this regard, the following recommendations, although general and not comprehensive, can be looked upon for addressing the obstacles discussed above and in the previous section [5,19].

(a) To reduce the cost of development and promote private participation in the development of SHP, emerging nations should carry out detailed investigations of their 
identified estimated potential and the detailed project report may be made available. The advanced nations must carry out potential re-assessment of identified sites and assessment of new sites based on contemporary technologies in the SHP sector, changing environmental conditions, policies and regulations, etc. The process of converting the prevailing infrastructure and rehabilitation of old sites to evolve a higher potential may also be considered.

(b) The major drawback faced by SHP developers is the lengthy time-consuming process for obtaining all the necessary clearances from various government departments and statutory bodies. A single-window clearance system should be established to mitigate this problem. Also, the existing policies and financial benefits which emphasized green energy technologies should be extended to SHP over and above the setting up of clearly stated targets for its development.

(c) One of the major drawbacks leading to low private sector participation in SHP development is the assumed high financial risk. A smooth, easy, and enhanced accessing procedure should be developed so that the developers can get the project financed successfully. Such a framework will also reduce the financial risk to investors. One way of achieving this is by creating consciousness regarding SHP among local financial institutions to improve the risk valuation and arrange for favorable loan circumstances. Also, skill development institutes should be set up to train and produce local skilled manpower to conduct various activities related to SHP development such as starting from pre-, during, and post-implementation of SHP projects to operation and maintenance of them. Such a framework would increase the self-sufficiency and long-lastingness of the SHP sector within a nation.

(d) Norms should be set up by the governments to set up industries with necessary benefits which will be producing the equipment required for construction, operation and maintenance of SHP plants using indigenous technology. In case of nations devoid of technology, facilities should be provided to provide easy access to foreign nations for purchase and import of equipment as well as implement reduced duties and tax structure for such imports.

(e) Several studies, especially in emerging nations show that SHP is faced with the problem of grid access where in some cases, the nearest grid accessible point is a few kilometres away. This poses an extra capital cost that should be borne either by the developer or government or in some cases jointly and adds to construction and time complexity. Also, in cases where grid access is available, the capacity or regulations posed by grid operator do not favor the integration of SHP. To attract private investment and aid in the development of the SHP sector, developing a robust grid with enough capacity to accommodate the newly developed SHP as well as accommodate the technical and operating changes brought in by them should be developed. In remote and isolated areas far off from the grid and which can provide enough base load, the development of micro and mini-grids will be a favorable and economical option for rural electrification as these provide electricity access and aid in economic development.

(f) For SHP to be preferred as a renewable energy option; there is an urgent need for cooperation between national and international stakeholders responsible for its development. This will enhance awareness and information exchange on new technologies, techno-economically feasible sustainable models, ownership issues, policies and regulations, benefits, and incentives which aid in SHP development and prevent adverse effects of climate change.

\section{Global SHP Development Scenario}

Small hydropower (SHP) is progressively considered as a vital renewable energy alternative to effectively answer the challenge of electrification of rural and isolated areas as well as adverse effects posed on the environment by climate change related to the energy sector. Though most nations in the west (especially Europe, and North and South America) 
and China in the east have a high percentage of installed capacity as compared to their estimated potential, the situation in many emerging nations is not the same as most of the estimated potential remains unexploited owing to several reasons which are both local and global. Several agencies and research institutes like the United Nations Industrial Development Organization (UNIDO), European Small Hydropower Association (ESHA), and Department of Hydro and Renewable Energy (HRED, formerly, Alternate Hydro Energy Centre, AHEC) of Indian Institute of Technology, Roorkee developed guidelines for aiding the SHP development at a faster pace [26-28]. In this section, a review of opinions by researchers following the SHP development scenario globally has been presented.

Alonso-Tristán et al. [29] highlighted that out of the total hydropower electricity generated in Spain, the share of SHP was 23\%. Out of the total installed hydropower, $10.6 \%$ is SHP. Spain is an excellent example of policies implemented to promote renewables, fulfilling the European commission's directive to achieve $20 \%$ of energy demand from renewable sources by 2020. Apart from highlighting the energy policies which led to the SHP development in Spain, the author also presented a techno-economic analysis for carrying out a pre-feasibility study for SHP installations.

Nautiyal et al. [30] and Saxena [31] presented the water resource and small hydro potential in India. In India even though the first SHP was established in 1897, stress to develop energy through renewable resources gained importance from 1992. SHP was considered as most beneficial as they are being used as standalone systems for decentralized power generation in remote and hilly areas, along with many other advantages, with cooperation from local communities, NGOs and private sector agencies. The estimated potential in India is $15,000 \mathrm{MW}$ whereas only $16 \%$ has been developed so far. The total installed capacity is $2429.77 \mathrm{MW}$ and $483.23 \mathrm{MW}$ is under implementation. Support from the Government is appreciable in establishing SHP projects throughout the country [32].

Tsoutsos et al. [33] presented a procedure under which SHP plant can be constructed and deployed, specifically in nations with complex governmental and statutory systems. This procedure is governed by the guidelines that portray sustainable spatial planning, with the objective of environmental fortification, to ensure healthier living circumstances and finally at the economic growth contained by the sustainability framework and its three basic dimensions: social, economic, and environmental.

Balat [34] presented the scenario of SHP in Turkey. Even though the SHP development began in 1902 with decentralized plants, but since the payback periods of SHP are not economically feasible, the trend shifted to the development of large power plants. Following the oil crisis in the 1970s, again SHP started to rebuild. Today Turkey's renewable sources are the second-largest source of energy production after coal. The total SHP potential is 50,000 Gwh/yr. The feasible technically and economically potential is 30,000 and $20,000 \mathrm{Gwh} / \mathrm{yr}$ respectively. So far, only $3.3 \%$ of feasible potential is exploited paving way for huge prospects in SHP development. Yuksel [35] discussed sustainable energy development in Turkey and hence discussed the strategies to mitigate the problem of evergrowing energy and electricity demand sustainably. The study revealed that the nation has an estimated hydropower potential of $433 \mathrm{GW}$ h/year, out of which only $125 \mathrm{GW}$ h/year is found to be techno-economically feasible.

Ohunakin et al. [36] discussed SHP development in Nigeria and opined that economic growth and energy consumption are strongly correlated. The first SHP in Nigeria was established in 1923, but the discovery of crude oil crippled its growth and expansion. The country has an estimated potential of $3500 \mathrm{MW}$, but only $30 \mathrm{MW}$ is harnessed. The main obstacles for this under development, despite abundant available natural resources, are the absence of long-term financing and competition for limited under macro-economic operating conditions. The support of the World Bank and the Government of Nigeria is appreciable in framing policies for the development of energy through renewable sources. Okedu et al. [37] discussed the SHP potential in Nigeria based on a ranking framework considering the cost of the SHP project. The criteria used in this work were the power in 
lean and peak season, economic feasibility, transmission cost, grid isolation, population growth, and government policies.

Reddy et al. [38] explored the relationship between local environmental and livelihood profits derived from SHP development in remote rural regions. The investigation was based on the study of SHP in the Himalayan and sub-Himalayan regions of India. They evaluated the impact of SHP on the community and also translated the environmental benefits arising, taking into account the participation and perception of the local population. It is highlighted that participation of the local population and providing them with direct livelihood benefits are vital because of SHP sustainability.

Montes et al. [39] discussed the renewable energy scenario in Spain with emphasis on small hydro power plants. Spain had an installed capacity of $1510 \mathrm{MW}$, which represents more than $15 \%$ of the $9800 \mathrm{MW}$ approximately developed in Europe, occupying the third place in Europe after Italy and France in Small Hydroelectric installations. The average growth is at $53 \mathrm{MW}$ a year, showing a fast evolution. The gross potential is evaluated to be $150,360 \mathrm{GW} \mathrm{h} / \mathrm{yr}$, technically feasible is $65,000 \mathrm{GW} \mathrm{h} / \mathrm{yr}$, out of this developed capacity is $31,600 \mathrm{GW}$ h/yr.

Hicks [40] described how China is attracting international attention with the creation of new records in world small hydro power development. China has an economically feasible potential of $100 \mathrm{GW}$, with 42,221 stations producing 28,489 MW and $2000 \mathrm{MW}$ being added annually. The main aim is to provide electricity for rural areas which in turn resulted in many benefits like rural economy development, reduced exploitation of forests and improved environmental protection by replacing firewood, flood control, and rural ecology improvement and protection of world-famous Giant Pandas through reduced deforestation.

Adu et al. [41] presented the SHP status and development in the Southern African Development Community. The work emphasized the need for a streamlined business model for SHP at both the national and global level. A combination of incentives at the local level and energy reforms can attract investments from the private sector. Furthermore, constant public support in the long term is essential, which highly depends on the government policies and political stability.

Signe et al. [42] presented a simple and effective method of carrying out feasibility studies for a micro hydro power plant in Cameroon to facilitate the development of SHP in that region which was reinforced by viability studies of the KEMKEN micro hydro power plant project. The project has an installed capacity of $320 \mathrm{~kW}$ with a Kaplan turbine and the investment cost was assessed at 21,2486,656 CFA franc with a payback period of 7 years. The authors summarized the methodology for feasibility studies to serve as a guide for sustainable micro hydropower development in the rural areas of Cameroon.

Ferreira et al. [43] presented an assessment of SHP potential in Brazil, which gained popularity as a nation for having the second largest hydro power plant in the world. The study identified that 475 SHPs are operating with a generation capacity of $4799 \mathrm{MW}$, which represents $3.49 \%$ of all Brazilian energy mix and with a projected installed capacity of $6500 \mathrm{MW}$ by 2020. The authors opined that there is still a vast potential accessible in the nation for SHPs, and can be exploited by following certain action policies such as paying more attention to government policies of the electricity sector, financiers providing agility in constructing new projects, clearly stating the advantages to the environment by SHP development to stakeholders and simplify procedures for approval. Filhoa et al. [33] presented a study that evaluated the projections of the growth in installed SHP capacity with the country's GDP.

Ciric [44] discussed the technical and economic aspects of the standalone and gridconnected operation of SHP plants, legal issues and environmental impacts in Serbia. The author proposed a multidisciplinary methodology to perform a complex analysis of assessing the techno-enviro-economic impact of an SHP plant at a specific site in Serbia. For such growth, main obstacles and threats for the development of the SHP capacity were acknowledged and to improve its penetration level with other renewable sources into the 
Serbian grid were suggested. The government must formulate policies to eliminate the barriers in SHP development and promote investments in the renewable energy sector.

Hatata et al. [45] opined that many SHP plants can be constructed as run-of-river schemes or executed on existing river infrastructures in Egypt for providing reliable, safe and affordable electricity. The authors recommend the Egyptian government formulate laws and regulations for hydropower to reduce dependence on fossil fuels to curb environmental pollution. To support their recommendations, research was carried out to investigate the SHP potential and feasibility at selected locations in the Nile delta. Based on five years of data, various techno-economic parameters have been considered in the investigation and concluded that Crossflow and Kaplan turbines with different sizes can enhance energy production.

Kaldellis [46] opined that to date Greece partially exploited its hydropower potential. Correspondingly, a huge number of private investors have publicly conveyed their interest in developing SHP schemes all over the nation, the reason being the incentives offered by the government for renewable energy schemes. However, to date, only a small number of projects have been realized due to government policies and the over sizing of the proposed installations. Undoubtedly, if the above difficulties are appropriately treated, SHP plants can be demonstrated significantly cost-effective investments, contributing also remarkably to the national electricity balance and substituting heavy polluting lignite and imported oil. Manzano-Agugliaro et al. [47] opined that even though Europe is the market leader for SHP technology, there is substantial scope for further development and optimization of SHP technology which could open new viewpoints as it has a huge and unexploited potential capable of effectively meeting future energy needs. New technical developments can lead to SHP automation.

Pang et al. [48] discussed China's aim to exploit the enormous hydropower potential of Tibet and proposed it as the main hydropower development base in China after 2020. The authors suggested that for improving the SHP sustainability in the region, greater emphasis should be put on the uprating of existing plants and strict policies for new development to adhere to the standards considering the fragile ecosystem of the region.

Sharma and Thakur [49] discussed the hydro policies; ecological, social, and economic issues; and other challenges related to the SHP schemes in Jammu and Kashmir. Although it has enormous hydro power potential, its complete potential has not been exploited so far. In recent years, the government is giving special consideration to this cost-effective source of hydro potential and several schemes in various regions of the state have been recognized. Some of these are in the planning stage and some are approved for execution after completing the investigation and design work. Giving due weightage to the Indus Water Treaty between India and Pakistan in 1960, all the hydropower schemes in the state are to be designed based on the run of the river type. For the development of large and small hydro schemes, the state government has developed separate hydro energy policies for these schemes.

Stevovic et al. [50] opined that the design processes must combine impacts related to non-technical criteria, through ecological and social impact evaluation studies. These studies are mainly evocative texts, conducted after the design optimization of the plant is completed and in most of the cases not included in the optimization studies. The authors presented a methodology for optimization considering all the non-technical criteria as fuzzy mathematical function in the decision-making process. Results concluded that considering both technical and non-technical criteria in the fuzzy optimized model leads to novel project solutions. The final designs were proven to be sustainable for development with minimal impact on the environment and local communities.

Uddin et al. [51] discussed the energy crisis in Pakistan and the role of SHP in partially mitigating this crisis. Only about $11 \%$ of the estimated hydropower potential of $60,000 \mathrm{MW}$ is operational. The development of SHP plants could reduce the country dependence on coal and oil by about 120 Mton and 83.3 billion liters. The existing fleet of small hydropower in Pakistan meets the energy demand of 0.7 million people and gives employment to 
0.2 million people. Yah et al. [52] discussed SHP status in Malaysia and its challenges. The estimated SHP potential is $500 \mathrm{MW}$. The barriers in SHP development were attributed mostly to economical and institutional challenges.

From the above literature survey on development aspects of SHP plants, it can be observed that investment and financing of SHP plants is a crucial phenomenon aiding the development of this energy sector. Hence, in the subsequent section, a review of economic analysis methods applicable to SHP plants was presented in detail. It can be concluded that, from the discussion in the present section, apart from finance and economics, the other reasons hindering the growth and development of the SHP sector are government/regulatory bodies' policies/initiatives which require reforms depending on the energy and environmental conditions existing in the respective nations.

\section{Cost Analysis of SHP Plants}

Allocation of limited natural resources to numerous needs that requires investment decisions is always pertinent and challenging. Projects in the energy industry, especially hydropower projects, require the assurance of huge amounts of funds for successful execution and operation. Cost analysis of most hydropower projects focuses on examining various costs and benefits with prominence on market conditions towards fulfilling their goals [53]. SHP project-based decisions on investments and other financial obligations are strongly established on an accurate and effective techno-economic and cost-benefit analysis [54]. Costs incurred during the development of an SHP project and projected benefits during the operation of the project are examined over the project's lifetime (in years). An SHP project with quantified benefits greater than the costs incurred, over the assessment duration, receive positive capital investments. Cost refers to the worth foregone to gain something in return. All business process comprises various costs which form the basis of profit determination for an organization. Cost analysis discusses the measure of the cost-output relationship, i.e., it is concerned with determining the cost incurred concerning input resources acquisition and how these can be effectively utilized to increase the productivity of the plant. Accordingly, cost classification is the logical process of categorizing the different costs involved in a process according to their type, nature, frequency, and other features to fulfil the objectives and facilitate the financial and economic feasibility of the SHP project [55].

The financial feasibility of an SHP project is examined for profitability, especially for projects driven by private player investments. Such a feasibility analysis takes into consideration the current market scenario: prevailing prices, inflation, and the adopted technology penetration level. The primary objective is to have a clear understanding of the level of estimated investments and expected profits out of those investments. The economic feasibility of the SHP project, on the other hand, is inclined towards non-monetary benefits which are for the general public. Such an analysis is conducted for SHP projects developed by public sector institutions or organizations whose primary portfolio is to enable the government in their activities of distributing the goods and services equally to the people. The economic analysis utilizes a framework that investigates the benefits of specific investments on the larger majority. While financial analysis deals with monetary benefits, economic analysis deals with monetary and societal benefits at large [55]. Such analysis lays down the techno-economic and financial feasibility of the small hydro power projects which provides a scientific base on final decision making on the deployment of the project. In general, the methods used are the pay-back, the benefit/cost ratio, the net present value, the internal rate of return, etc. The most straightforward process to work out the economic advantage of investment in SHP plant is to evaluate the payback period for the investments made in the development and construction of the said project. The payback period of a small hydro power project is dependent on the current state of the financial market. The state of the market is determined by economic factors such as borrowed capital and its interest, inflation, applicable tariffs, and like-wise. The usual practice is to augment the income and expenditure, over the trading period of the project development. Such 
practice shall assist to compensate for inflation. However, evaluation of the time value of money for such projects, in later years, becomes interminable. Due to such a lack of clarity on the relationship between the time value of money and present value, economic metrics of present worth, net present value, or discount cash flow methods are often deployed. In the following section, a review of various economic/ cost analysis methods applicable to small hydro plants has been presented.

Abdullahi et al. [56] presented a feasibility study of developing an SHP plant for rural electrification in Nigeria using HOMER. The paper addressed the feasibility of integrating SPV or grid to an existing SHP plant. Off-grid and grid-connected analysis was carried out for hydro-diesel-battery-converter configuration and grid-hydro configuration respectively. A net present cost of $\$ 19,717$ and $\$ 2398$ respectively was reported. The reduction in NPV in the second case is because excess electricity could be sold back to the grid.

Chatzimouratidis et al. [57] state that power plant assessment complexity is gradually increasing, as more criteria are incorporated in the overall assessment while data required for evaluation keeps on changing rapidly. Ten types of power plants are assessed using nine end-node criteria appropriately structured under the analytical hierarchy process. It is a multi-criteria analysis based on hierarchically structured criteria which are necessary to address the overall assessment of power plants according to the technological, economic, and sustainability aspects. Results indicated that based on the subjective criteria weighting, power plants based on renewables emerged at the top of the overall ranking, while nuclear and fossil fuel power plants rank in the last five positions.

Sarala [58] proposed measures for reducing the cost of SHP plants by analyzing two mini-hydro schemes, Bhimgarh small hydro and Chargaon-Jatlapur Mini hydro schemes in India, installed as dam toe and canal-based fall respectively. The various costs of civil works, cross-regulation, intake structure, and bypass canal have been analyzed to calculate the cost-benefit ratio and annualized return. The cost estimates for electromechanical equipment were prepared and the annual fixed cost worked out to be INR 3.08 million. The paper also focused on constraints and problems arising in the development of SHP plants and suggests developing pico-hydel schemes which do not require the construction of dams and considered as run off river plants. A simplified prototype model has been developed, tested, and validated. Results summarize the usefulness of pico hydro systems in making remote villages with a lack of grid power becoming self-reliant.

Dutta et al. [59] reviewed the build-own-operate-transfer (BOOT) model in Nepal for developing the hydel schemes based on economic indices which incorporates the quantified socioeconomic cost-benefits. The paper focuses on economic indices to predict the project's performance when the ownership is transferred to the government from private developers. Economic analysis has been performed on an SHP scheme to be constructed in the Dolakha district of Nepal. Economic analysis results indicate that internal rate of return, net present value, benefit-cost ratio, and payback period are found positive. The project is economically feasible even at a $90 \%$ certainty level where there could be a possible reduction in energy generation by $20 \%$; increase in project cost by $20 \%$ or in both conditions. It has been observed that in the combined scenario, the economic internal rate of return, economic net present value, the benefit-cost ratio is marginally convincing at $90 \%$ certainty, but the project is feasible.

Several studies have been reported on developing a mathematical equation describing the costing of the SHP scheme under different executing and market conditions. Ogayar and Vidal [60] found an equation to compute the cost of the electromechanical equipment based on the head and installed capacity of an SHP plant. Both reaction (propeller, Francis) type and impulse (Pelton wheel and cross-flow) type turbines were considered in the development of the cost equation. Results of the research indicate that either for the renovation of an old SHP plant or construction of a new SHP plant, the proposed methodology helps to determine the initial capital investment. It was observed that the difference between simulated and actual costs is negligible. It was also found that many of the cost equations obtained by different authors in literature were almost like that of the 
real cost. Ogayar et al. [61] discussed cost analysis of refurbishing SHP schemes. A costoptimal strategy was developed to conduct the feasibility study of the refurbishment task. Approximated costs for the refurbishment of old and new SHP projects were computed based on unitary prices which can be applied to any country.

One of the methods adopted in developing small hydro projects has been the build operate and transfer (BOT) mechanism. Forouzbakhsh et al. [62] presented an extensive study on BOT driven SHP projects. Increased participation of the private players assists in handling the heavy investments in the construction of capital-intensive powerhouses under BOT. Studies have demonstrated substantial improvement in the NPV and economic value of the SHP scheme developed under BOT schemes. The burden on the state and union governments during the execution of the SHP projects also reduces under the BOT mechanism. Risks associated with the SHP project are shared among different stakeholders.

Technical parameters for the SHP project-such as flow rate, gross and net head, power potential, and power available-are taken into consideration while estimating the costs of electro-mechanical equipment of the SHP project [63]. All reaction (propeller, Francis) and impulse (Pelton wheel, cross-flow) turbines were considered in developing cost equations correlated to already published literature.

Carapellucci et al. [64] conducted techno-economic analysis for the SHP projects installed at an Italian region of Abruzzo. Flow duration curves of about 90 different branches of a river were characterized graphically. Rated power generation from the proposed SHP project was assessed and annual electrical energy generation in kWh was analyzed by developing an energy system model. The developed model was based on the annual flow duration of the stream under study and the turbine technology deployed in the powerhouse of the plant. The cost of electrical energy generated was evaluated taking into considerations both variable and fixed costs. The financial feasibility of the SHP scheme was conducted based on the capital investment incurred. To enhance the economic and financial feasibility of the project, the net power generation was adjusted and the techno-economic effectiveness was demonstrated at different power potentials of the project.

Cost optimization studies for SHP schemes have also been developed for optimal selection of the hydro-mechanical equipment such as turbines, draft tubes, etc. A simple survey-based cost-benefit analysis was developed by Zema et al. [65] for a Micro Hydro Power (MHP) scheme in Calabria, Italy. The stream used for the study was an irrigation canal and an optimal location of installing a hydro turbine, at a maximum power output operating point, was demonstrated. However, the study also revealed that low power output (up to $5 \mathrm{~kW}$ ) turbines would not yield any major financial benefit by installing few high-power output turbines. A similar situation was encountered when several low power output turbines were included in the same study. Design changes to the penstock/pipe radium yielded financial benefits for the same power output requirement and an enhanced return on investment as compared to the existing market prices. Moreover, the financial benefits would improve over the operational period of the MHP plant where the canal can be utilized for irrigation purposes for six months and MHP power generation in the remaining six months, for every year.

Balkhair et al. [66] proposed an economically sustainable resolution for the evergrowing demand for electrical power through SHP projects. Numerous sites along the Swat River were explored in the northern region of Khyber-Pakhtunkhwa Province in Pakistan. Discharge and head were examined in all the sites. Design parameters such as differential head, stream velocity, accessibility, habitats nearby, and the necessary geophysical investigation were evaluated. Gross electrical power output was evaluated for every individual site under examination based on discharge, head and hydraulic information. The cost of electrical energy produced per unit was calculated as a ratio of average annualrecurring cost to the annualized production of electrical energy over the lifetime of the SHP operation. Each site that was investigated for the installation of a feasible SHP project could provide reliable electric service to more than 1500 households. Incentivizing the cost 
to be incurred for the SHP project development would lead to electrical power generation of around $21 \%$ of the total production of the swat rover stream.

Kishore et al. $[67,68]$ presented a life cycle costing based methodology for Levelized cost of electricity (LCOE) determination for high and low head SHP plants. A major portion of capital investment in the current small hydropower sector is due to the cost of equipment and construction process. neglecting the cost of plant outage, generation loss, operation and maintenance, replacement costs, etc. For cost administration and decision making, SHP developers in recent years are drawing more awareness towards performing life cycle costing studies that account for these neglected costs. Research revealed that for high head plants civil work costs are more than electromechanical component costs and vice versa for low head plants, both the costs depending on head and capacity, which are crucial in arriving at the overall cost of the plant. The life cycle costing formulation for LCOE is discussed in Supplementary S2.

Conducting cost-benefit analysis for SHP projects makes both technical and economic sense and is imperative during the pre-design and design stage [69]. However, the parameters to be considered for the said analysis usually vary from project to project. Sensitivity analysis is, usually, carried for parameters that may be sensitive for output power generation and annualized electricity generation but at a minimal cost of design and operation. Filho et al. [65] used a parameter called "aspect factor" to evaluate the cost of electrical power generation and demonstrated it for SHP schemes in India and Brazilian streams. The developed technique using aspect factor was validated against already published statistical methods.

The Himalayan region of India has housed hydroelectric power plants which are centuries old. Rahi and Kumar [70] developed a refurbishment strategy for older SHP plant which shall have minimum capital investments and maximum gains through enhanced power generation capacity. Moreover, the time duration for refurbishment and uprating of the SHP plant understudy would be minimum based on the strategy developed.

Singal and Saini [71,72] and Singal et al. [73] presented an analysis for costs of civil and electromechanical works to arrive at the final cost of the total project for canal-based and run of river SHP schemes. Canal-based SHP projects were analyzed under different power capacities and net head calculations. Mathematical correlations (using regression analysis) were developed for low head SHP projects under various capacities. Cost equations were developed for electro-mechanical and civil components of the low head canal-based SHP projects. Costing per $\mathrm{kW}$ power capacity of the component increases with a decrease in net head and power capacity.

Low head plants were also analyzed by Singal and Saini [74] taking into consideration the $\mathrm{kW}$ capacity and gross head. Analysis was performed for developing correlations for various cost constituents of low-head dam-toe SHP plant with tubular turbines integrated with synchronous generators with a range of 3-20 m head and 1-5 kW unit size. The developed correlations indicated that cost $/ \mathrm{kW}$ reduces with a corresponding increase in net head and capacity. To know the realistic cost of low head dam-toe SHP plants, the correlations for the cost of various constituents of these schemes were determined using regression analysis centered on actual quantities of several constituents and prevalent rates. This will be useful in knowing the SHP scheme cost which is the primary necessity for taking up a project for development. 
Singal et al. [72,75] developed a cost-optimal design strategy for low-head, dam-toe based SHP projects. The financial feasibility of such projects, at different load factors, was examined based on sensitivity analysis. For load factors higher than 0.9 p.u., propeller runner based tubular turbine shall operate with maximum financial internal rate of return (FIRR). For load factors of 0.6-0.8 p.u., semi-Kaplan runner based tubular turbine is optimum and for lower load factors Kaplan runner-based bulb turbines shall work optimally. For SHP projects, whose FIRR is greater than the interest rates are financially feasible.

Mishra et al. [76,77] in their research stated that the installation cost of a small hydro plant mainly depends on civil works and electromechanical equipment. The author developed correlations to determine the cost based on head and power output using three different methods via sigma plot, linest, and logest methods. The results obtained by these methods show the percentage error when compared with actual cost data and are found to be $10 \%, 5 \%$, and $18 \%$ for sigma plot, linest, and logest methods respectively. It is concluded that the sigma plot and linest methods are very close to actual cost and can be used for planning purpose.

Mishra et al. [78] developed a method for cost evaluation of high-head run-of-river (ROR) SHP schemes for determining their technical and economic feasibility before taking up comprehensive investigations. Such a study will be helpful to SHP planners and developers to go ahead with comprehensive investigations and construction of merely, the projects which are found to be techno-economically viable. Power capacity in $\mathrm{kW}$ and head availability in meters was used to examine the costs incurred. Regression-based correlations were obtained for different parameter ranges of headrace, tailrace, different materials of the penstock, impulse and reaction turbine types, and synchronous generators. Correlations obtained were validated against the already published articles available in the literature. It was demonstrated that the proposed cost correlations can be useful for approximate cost estimation of SHP schemes with reasonable accuracy for planning purposes. A cost-optimal layout selection strategy was developed using particle swarm optimization (PSO) technique and applied to the SHP project. The cost analysis based on the correlations is presented in Supplementary S2.

Also, most of the research is dependent on correlations for arriving at the various costs associated with the SHP plant in terms of cost influencing parameters. In this context, Tables 3 and 4 present the correlations developed for various cost components of high and low head SHP plants respectively, operating in the Indian sub-continent.

Barros and Peypoch [79] analyzed the technical effectiveness in hydropower plants in Portugal exploring the role played by increasing competition and regulation by considering the random cost frontier method. A translog frontier model and the highest likelihood assessment technique was considered to assess the empirical model. The effectiveness was assessed by allotting scores for efficiency and decomposition of exogenous variables into homogeneous and heterogeneous variables was carried. Results indicated that power generation and installed capacities are heterogeneous, suggesting that the hydropower plants are very different and, consequently, any energy strategy should mandatorily consider this heterogeneity. The results of this study also concluded that competition, rather than regulation, plays a significant and crucial role in increasing hydropower plant efficiency.

Gagliano et al. [80] evaluated the technical and economic feasibility of reusing an old and abandoned mini hydropower plant in Italy. The reactivation of mini hydropower plant allows producing energy from renewable source contributing to the energy independence of the local community, with an estimated yearly energy production of about $220 \mathrm{MWh}$. The techno-economic evaluation of the mini hydropower plant is done using MadoWatt tool, developed in MATLAB environment. The study concludes that several opportunities for the developments of small hydropower plants subsist in Italy and worldwide, which if properly designed and realized should lead to considerable results in terms of both renewable energy production and profits. 
Table 3. Correlations for cost components of high head SHP plants [78].

\begin{tabular}{|c|c|c|c|c|c|c|}
\hline \multirow[b]{2}{*}{ Sl. No. } & \multirow{2}{*}{\multicolumn{2}{|c|}{ Civil Work Components }} & \multicolumn{4}{|c|}{ Correlations } \\
\hline & & & $\begin{array}{l}\text { Earth Work in } \\
\text { Excavation }\left(\mathrm{m}^{3}\right)\end{array}$ & Concreting $\left(\mathrm{m}^{3}\right)$ & Reinforcement Steel (MT) & $\begin{array}{c}\text { Structural } \\
\text { Steel/Material (MT) }\end{array}$ \\
\hline 1 & \multicolumn{2}{|c|}{ Diversion Weir } & $47 \mathrm{P}^{1.1} \mathrm{H}^{-0.99}$ & $38.55 \mathrm{P}^{1.17} \mathrm{H}^{-1.16}$ & $2.59 \mathrm{P}^{1.18} \mathrm{H}^{-1.15}$ & $1.51 \mathrm{P}^{0.71} \mathrm{H}^{-0.67}$ \\
\hline 2 & \multicolumn{2}{|c|}{ Intake channel } & $2.99 \mathrm{P}^{0.85} \mathrm{H}^{-0.91}$ & $1.82 \mathrm{P}^{0.87} \mathrm{H}^{-0.91}$ & $0.03 \mathrm{P}^{0.82} \mathrm{H}^{-0.87}$ & - \\
\hline 3 & \multicolumn{2}{|c|}{ Desilting tank } & $1770 \mathrm{P}^{0.83} \mathrm{H}^{-1.02}$ & $836.96 \mathrm{P}^{0.79} \mathrm{H}^{-1.01}$ & $9.81 \mathrm{P}^{0.76} \mathrm{H}^{-0.92}$ & $2.96 \mathrm{P}^{0.83} \mathrm{H}^{-1.01}$ \\
\hline \multirow{5}{*}{4} & \multirow{5}{*}{ Head Race } & Channel & $2.99 \mathrm{P}^{0.85} \mathrm{H}^{-0.91}$ & $0.81 \mathrm{P}^{0.88} \mathrm{H}^{-0.94}$ & $0.02 \mathrm{P}^{0.22} \mathrm{H}^{-0.25}$ & - \\
\hline & & PVC pipe & $2 \mathrm{P}^{0.84} \mathrm{H}^{-0.95}$ & $0.13 \mathrm{P}^{0.87} \mathrm{H}^{-0.98}$ & $0.01 \mathrm{P}^{0.82} \mathrm{H}^{-0.92}$ & $0.01 \mathrm{P}^{1.5} \mathrm{H}^{-0.93}$ \\
\hline & & MS pipe & $2 \mathrm{P}^{0.84} \mathrm{H}^{-0.95}$ & $0.13 \mathrm{P}^{0.87} \mathrm{H}^{-0.98}$ & $0.01 \mathrm{P}^{0.82} \mathrm{H}^{-0.92}$ & $0.02 \mathrm{P}^{1.1} \mathrm{H}^{-1.24}$ \\
\hline & & GRP pipe & $2 \mathrm{P}^{0.84} \mathrm{H}^{-0.95}$ & $0.13 \mathrm{P}^{0.87} \mathrm{H}^{-0.98}$ & $0.01 \mathrm{P}^{0.82} \mathrm{H}^{-0.92}$ & $0.01 \mathrm{P}^{1.5} \mathrm{H}^{-0.5}$ \\
\hline & & Tunnel & $0.08 \mathrm{P}^{0.98} \mathrm{H}^{-0.95}$ & $0.83 \mathrm{P}^{0.71} \mathrm{H}^{-0.69}$ & - & $0.02 \mathrm{P}^{0.96} \mathrm{H}^{-0.93}$ \\
\hline 5 & \multicolumn{2}{|c|}{ Surge tank } & $0.04 \mathrm{P}^{0.98} \mathrm{H}^{0.19}$ & $0.04 \mathrm{P}^{0.98} \mathrm{H}^{0.2}$ & $0.03 \mathrm{P}^{0.98} \mathrm{H}^{0.19}$ & - \\
\hline 6 & \multicolumn{2}{|c|}{ Forebay and spillway } & $1339.43 \mathrm{P}^{0.5} \mathrm{H}^{-0.69}$ & $70.31 \mathrm{P}^{0.73} \mathrm{H}^{-0.63}$ & $5.22 \mathrm{P}^{0.72} \mathrm{H}^{-0.61}$ & $5.62 \mathrm{P}^{0.58} \mathrm{H}^{-0.7}$ \\
\hline \multirow{4}{*}{7} & \multirow{4}{*}{ Penstock } & PVC pipe & $0.42 \mathrm{P}^{0.83} \mathrm{H}^{-0.98}$ & $0.31 \mathrm{P}^{0.84} \mathrm{H}^{-0.98}$ & $0.03 \mathrm{P}^{0.83} \mathrm{H}^{-0.97}$ & $0.00004 \mathrm{P}^{1.5} \mathrm{H}^{-0.81}$ \\
\hline & & GRP pipe & $0.42 \mathrm{P}^{0.83} \mathrm{H}^{-0.98}$ & $0.31 \mathrm{P}^{0.84} \mathrm{H}^{-0.98}$ & $0.03 \mathrm{P}^{0.83} \mathrm{H}^{-0.97}$ & $0.000009 \mathrm{P}^{1.5} \mathrm{H}^{-0.8}$ \\
\hline & & HDPE pipe & $0.42 \mathrm{P}^{0.83} \mathrm{H}^{-0.98}$ & $0.31 \mathrm{P}^{0.84} \mathrm{H}^{-0.98}$ & $0.03 \mathrm{P}^{0.83} \mathrm{H}^{-0.97}$ & $0.000008 \mathrm{P}^{1.5} \mathrm{H}^{-0.8}$ \\
\hline & & Steel pipe & $0.42 \mathrm{P}^{0.83} \mathrm{H}^{-0.98}$ & $0.31 \mathrm{P}^{0.84} \mathrm{H}^{-0.98}$ & $0.03 \mathrm{P}^{0.83} \mathrm{H}^{-0.97}$ & $0.05 \mathrm{P}^{0.83} \mathrm{H}^{-0.95}$ \\
\hline 8 & \multicolumn{2}{|c|}{ Tail Race channel } & $2.29 \mathrm{P}^{0.85} \mathrm{H}^{-0.91}$ & $1.82 \mathrm{P}^{0.87} \mathrm{H}^{-0.91}$ & $0.01 \mathrm{P}^{0.8} \mathrm{H}^{-0.79}$ & - \\
\hline \multirow{2}{*}{9} & \multirow{2}{*}{ Powerhouse building } & Pelton/Turgo/Impulse & $16.09 \mathrm{P}^{2.46} \mathrm{H}^{-1.75}$ & $0.0005 \mathrm{P}^{2.54} \mathrm{H}^{-0.42}$ & $0.00022 \mathrm{P}^{4.02} \mathrm{H}^{-2.83}$ & $0.0009 \mathrm{P}^{4.55} \mathrm{H}^{-3.5}$ \\
\hline & & Francis & $0.08 \mathrm{P}^{2.33} \mathrm{H}^{-1.33}$ & $0.03 \mathrm{P}^{2.29} \mathrm{H}^{-1.32}$ & $0.05 \mathrm{P}^{2.36} \mathrm{H}^{-1.34}$ & $0.02 \mathrm{P}^{2.19} \mathrm{H}^{-1.26}$ \\
\hline
\end{tabular}


Table 3. Cont

\begin{tabular}{|c|c|c|c|c|c|}
\hline \multirow[b]{2}{*}{ Sl. No. } & \multirow[b]{2}{*}{ Civil Work Components } & \multicolumn{4}{|c|}{ Correlations } \\
\hline & & $\begin{array}{l}\text { Earth Work in } \\
\text { Excavation }\left(\mathrm{m}^{3}\right)\end{array}$ & Concreting $\left(\mathrm{m}^{3}\right)$ & Reinforcement Steel (MT) & $\begin{array}{c}\text { Structural } \\
\text { Steel/Material (MT) }\end{array}$ \\
\hline \multicolumn{6}{|c|}{ Electromechanical Components } \\
\hline \multirow{3}{*}{10} & \multirow{3}{*}{\multicolumn{2}{|c|}{ Turbine governing system }} & Pelton & 117,313 & $\mathrm{I}^{-0.39}$ \\
\hline & & & Turgo impulse & 145,121 & $\mathrm{H}^{-0.24}$ \\
\hline & & & Francis & 125,354 & $\mathrm{H}^{-0.38}$ \\
\hline 11 & \multicolumn{2}{|c|}{ Generator with excitation system or capacitor bank } & Synchronous & 143,660 & $\mathrm{H}^{-0.21}$ \\
\hline 12 & \multicolumn{3}{|c|}{ Auxiliaries } & $21,846 \mathrm{I}$ & {$[-0.22$} \\
\hline 13 & \multicolumn{3}{|c|}{ Transformer } & $221 \mathrm{I}$ & \\
\hline 14 & \multicolumn{3}{|c|}{ Switchyard } & 1.821 & \\
\hline
\end{tabular}


Table 4. Correlations for cost components of low head SHP plants [71,73,75].

\begin{tabular}{|c|c|c|}
\hline Components $\rightarrow$ SHP Type $\downarrow$ & Civil Works Components & ElectromechanicalComponents \\
\hline Run of River SHP & $\begin{array}{c}\mathrm{C}_{\mathrm{PHB}}=92,615 \mathrm{P}^{-0.2351} \mathrm{H}^{-0.0585} \\
\mathrm{C}_{\mathrm{DW} \mathrm{I}}=12,415 \mathrm{P}^{-0.2368} \mathrm{H}^{-0.0597} \\
\mathrm{C}_{\mathrm{PC}}=85,383 \mathrm{P}^{-0.3811} \mathrm{H}^{-0.0307} \\
\mathrm{C}_{\mathrm{DC}}=20,700 \mathrm{P}^{-0.2385} \mathrm{H}^{-0.0611} \\
\mathrm{C}_{\mathrm{F} \& \mathrm{~S}}=25,402 \mathrm{P}^{-0.2356} \mathrm{H}^{-0.0589} \\
\mathrm{C}_{\mathrm{P}}=7875 \mathrm{P}^{-0.3806} \mathrm{H}^{0.3804} \\
\mathrm{C}_{\mathrm{TR}}=28,164 \mathrm{P}^{-0.376} \mathrm{H}^{-0.624}\end{array}$ & $\begin{array}{c}\mathrm{C}_{\mathrm{TG}}=63,346 \mathrm{P}^{-0.1913} \mathrm{H}^{-0.2171} \\
\mathrm{C}_{\mathrm{GE}}=78,661 \mathrm{P}^{-0.1855} \mathrm{H}^{-0.2083} \\
\mathrm{C}_{\mathrm{AUX}}=40,860 \mathrm{P}^{-0.1892} \mathrm{H}^{-0.2118} \\
\mathrm{C}_{\mathrm{T} \& \mathrm{SY}}=18,739 \mathrm{P}^{-0.1803} \mathrm{H}^{-0.2075}\end{array}$ \\
\hline Dam Toe SHP & $\begin{array}{c}\mathrm{CI}=17,940 \mathrm{P}-0.2366 \mathrm{H}-0.0596 \\
\mathrm{CP}=7875 \mathrm{P}-0.3806 \mathrm{H} 0.3804 \\
\mathrm{CPHB}=85,717 \mathrm{P}-0.2355 \mathrm{H}-0.0588 \\
\mathrm{CTR}=28,164 \mathrm{P}-0.376 \mathrm{H}-0.624\end{array}$ & $\begin{array}{c}\text { CTG }=66,282 \mathrm{P}-0.1866 \mathrm{H}-0.2094 \\
\text { CGE }=79,927 \mathrm{P}-0.1854 \mathrm{H}-0.2097 \\
\text { CAUX }=39,372 \mathrm{P}-0.1865 \mathrm{H}-0.2107 \\
\text { CT\&SY }=18,739 \mathrm{P}-0.1803 \mathrm{H}-0.2075\end{array}$ \\
\hline Canal-based SHP & $\begin{array}{c}\mathrm{C}_{\mathrm{PHB}}=105,555 \mathrm{P}^{-0.238} \mathrm{H}^{-0.0602} \\
\mathrm{C}_{\mathrm{S}}=36,778 \mathrm{P}^{-0.2306} \mathrm{H}^{-0.0644} \\
\mathrm{C}_{\mathrm{DW}}=9909 \mathrm{P}^{-0.2295} \mathrm{H}^{-0.0623}\end{array}$ & $\begin{array}{c}\mathrm{C}_{\mathrm{TG}}=63,346 \mathrm{P}^{-0.1913} \mathrm{H}^{-0.2171} \\
\mathrm{C}_{\mathrm{GE}}=78,661 \mathrm{P}^{-0.1855} \mathrm{H}^{-0.2083} \\
\mathrm{C}_{\mathrm{AUX}}=40,860 \mathrm{P}^{-0.1892} \mathrm{H}^{-0.2118} \\
\mathrm{C}_{\mathrm{T} \& \mathrm{SY}}=18,739 \mathrm{P}^{-0.1803} \mathrm{H}^{-0.2075}\end{array}$ \\
\hline
\end{tabular}

PHB = Power House building; DW = Diversion weir I = Intake; PC = Power channel; DC = Desilting chamber; F = Forebay; $\mathrm{S}=$ Spillway; $\mathrm{P}=$ Penstock; TR = Tail race; TG = Turbine governor system; $\mathrm{GE}=$ Generator and excitation system; $\mathrm{AUX}=$ Mechanical and electrical auxiliaries; T\&SY $=$ Transformer and switchyard.

Santolin et al. [81] demonstrated a method for capacity sizing of a single turbine SHP project based on techno-economic analysis. The method aims at evaluating the influence of design operating conditions on plant performance and investment profitability basing on the flow available at the site considering seven technical parameters: turbine type, machine dimensions, annual energy production, maximum installation height to avoid cavitation, machine cost, NPV, and IRR. It is inferred that simultaneous technical and economic analysis allows one to choose proper design operating condition based on performance, profitability, and feasibility of the plant.

Aggidis et al. [82] developed an empirical formula providing a solution to quickly compute the least cost of investing in potentially available SHP schemes and the associated costs of energy generation, electro-mechanical equipment, and turbine type based on the hydraulic characteristics (head and discharge), which will further be useful in determining the maximum power generation capacity that can be installed. The cost analysis of the various turbine type establishes its connection with the SHP's hydraulic characteristics. The costs involved in the manufacturing of the turbines possess the probability to alter based on the size and type of the turbine. The computed results can be compared with the estimations attained from other methodologies and will help assist further activities, such as economic valuation and financing.

Dudhani et al. [83] presented the use of remote sensing information for identifying and selecting sites favorable for constructing hydropower plants. A systematic and all-inclusive methodology to collect data required for identifying and assessing water resources, land use and land cover, snow cover, inhabitation and settlement pattern, and identification of probable sites for SHP schemes, etc. obtained through satellite imagery was discussed. Significant saving of manpower and time required for surveying and updating the information of potential SHP scheme sites with a certain level of accuracy will considerably affect the cost.

Singhal and Kumar [84] elucidated that cost estimates for several civil structures are highly significant in the design planning and execution of mini/micro hydropower schemes. Cost curves were constructed using regression analysis for civil structures centered on several such schemes which are under execution. These cost curves will help estimate civil structures cost based on site-specific parameters. 
Montanari [85] presented a novel methodology to identify a highly economical alternative for the construction of MHP schemes. The developed methodology involved evaluating the net present value (NPV) of the project scheme under study. NPV was formulated based on nominal/design flow rate, net and gross head and the hydraulic characteristics, specific to a site. Results are obtained in the form of cost $/ \mathrm{kW}$ of installed capacity. However, there exists a high correlation concerning turbine cost and flow rate rather than installed capacity. Nevertheless, as soon as a site is identified, the net head will remain the same for any number of possible designs. Under the assumption of a long weir availability, the net head computed, remains constant w.r.t. the nominal flow rate. Henceforth, it becomes viable to correlate the scheme-specific costs to the installed power capacity of the project. It has also been observed that cost $/ \mathrm{kW}$ reduces with installed capacity increase. Also, based on the operational life of the plant and the interest rate is fixed, it is probable to assess the differential net present value for different designs under consideration.

Kaldellis et al. [86] discussed the research conceived on the systematic examination of the SHP's techno-economic feasibility. A sensitivity analysis approved for the local market financial condition to inform the investors on the probable profits that can be expected from the invested capital was demonstrated. The methodology applied was centred on a well-explained theoretical model about real-time market technical and economic data obtained over a significant period. It was forecasted that the resultant economic parameter value, i.e., the internal rate of return of the SHP scheme is higher than $18 \%$ for most of the cases. It has been observed that the internal rate of return value reaches a maximum after 10-15 years of successful operation of the SHP scheme.

Archetti [87] presented the feasibility analysis of an SHP scheme in Italy, in terms of technical and economic parameters. Four solutions are obtained considering different combinations of pipes, turbines, storage tanks, and the possibility of selling energy or consuming for own use. The one with a Pelton turbine coupled to a permanent magnet generator that powers a DC inverter directly connected to the load is found to be most economical. This option also considers tax benefits related to remodeling and has a lower amortization period of 8 years.

Singh and Singal [88] stated that a non-linear constrained mathematical modeling taking into account the operating costs and yearly energy production would be effective for optimization of SHP operation. The optimization results from the objective function, which comprises the yearly energy production and operating cost as the existing models available in the literature did not consider the operating cost and focused only on the energy production. The results attained indicated that the present model was superior in delivering maximum yearly profit and optimal values for operating parameters.

Singh and Singal [89] argued that among the various renewable energy sources, small hydropower is considered the most promising energy source. For proper operation of the SHP plant, the annual generation and operational cost are the two main aspects. To maintain the economy of operation, it is necessary to minimize the operation cost with improved performance. The authors developed a correlation for run-of-the-river SHP schemes, bearing in mind the cost-influencing variables, the head, and the installed capacity. They concluded that the correlation developed for operation cost can be used to determine the operation cost at the planning stage.

Kumar et al. [90] established the maintenance cost correlations for the high head run of river SHP schemes basing on power generation capacity and net head as the parameters influencing the cost using the linear regression technique in MATLAB environment. The results obtained indicated that the highest deviation observed was $\pm 12.60 \%$, the highest average deviation cost attained for the turbine is $\pm 11.35 \%$ and the lowest average deviation cost for thrust bearing was $\pm 3.5 \%$. The average deviation observed in the maintenance cost was found to be $\pm 7.35 \%$, which indicates that the established correlations are in line with the existing benchmark as well as prevailing costs of existing schemes. Hence, these correlations can aid in determining the maintenance cost of high head SHP. 
Anagnostopoulous and Papantonis [91] presented a numerical procedure for optimal sizing of a plant with two parallel operating turbines. The evaluation algorithm used for plant performance analysis can simulate the detailed process of plant operation and calculates its energy generation statistics and economic parameters. For determining the influence of factors about constructing and operating the plant, a parametric study based on stochastic optimization was undertaken. Evolutionary algorithms were utilized to solve the stochastic problem. Results obtained indicated that using two different turbines in terms of size can enhance power production as well as investment returns.

Hosseini et al. [92] ascertained the SHP's optimal installation capacity and its yearly energy value. The net yearly energy produced was computed using an Excel-based software program. It analyzes and estimates the economic parameters of an SHP scheme using sensitivity analysis. Also, a Monte Carlo methodology-based software program was established to compute the reliability indices based on the real-time data obtained from various SHP generating units which are subjected to specific loads. Finally, optimum installation capacity was identified by evaluating the techno-economic-reliability indices.

Nouni et al. [93] discussed supplying power to remote areas in India through the decentralized operation of micro hydropower schemes. A technical and economic viability assessment of these schemes for better planning and implementation was conducted by analyzing capital cost, rated capacity cost per MW, and comparative cost of all sub-systems. The results obtained in terms of electricity delivered cost per unit, plant load factor, and economic parameters - such as breakeven value-indicate that the procedure adopted is highly useful for the initial assessment of these schemes before starting execution works.

Bøckman et al. [94] state that there is a unique price limit for initiating a project based on the real options-based method for SHP schemes. In the present research, the decisions for investment making are based on finding the value of the scheme if executed and the capital investment. The primary objective of the study was to optimally size the SHP project based on the risk-adjusted price of electrical energy produced in the long-term. The present real options method also considers the possibility of postponing the investment choice to acquire further data and information regarding the financial viability of the scheme.

Aslan et al. [95] performed a sensitivity analysis for the existing Kayabogazi dam in Kutahya in Turkey. In this analysis, seven different cases have been evaluated considering the position of the turbine and the number of turbines. Despite the variable flow rates, the combination of two crossflow turbines is more efficient. An additional Francis turbine coupled with an automatic control system could take care of high flow rates, to maximize the power generation.

The above literature survey on economic analysis methods applicable to SHP plants indicates that project financing in the form of various costs and their management is essential at every stage for optimal operation of the SHP plant and reap benefits from the sale of electricity, thereby making the SHP sector a sustainable business perspective. In this context, from the research carried out worldwide it can be observed that these cost influencing parameters are the net head and power generating capacity of the SHP plant. Table 5 gives more informative data on the parameters considered in the economic analysis procedures adopted by various authors, compares various economic analysis methods and summarizes information about the task considered, the methodology adopted, and various costs of components considered in the models. 
Table 5. Comparison of various economic analysis methods

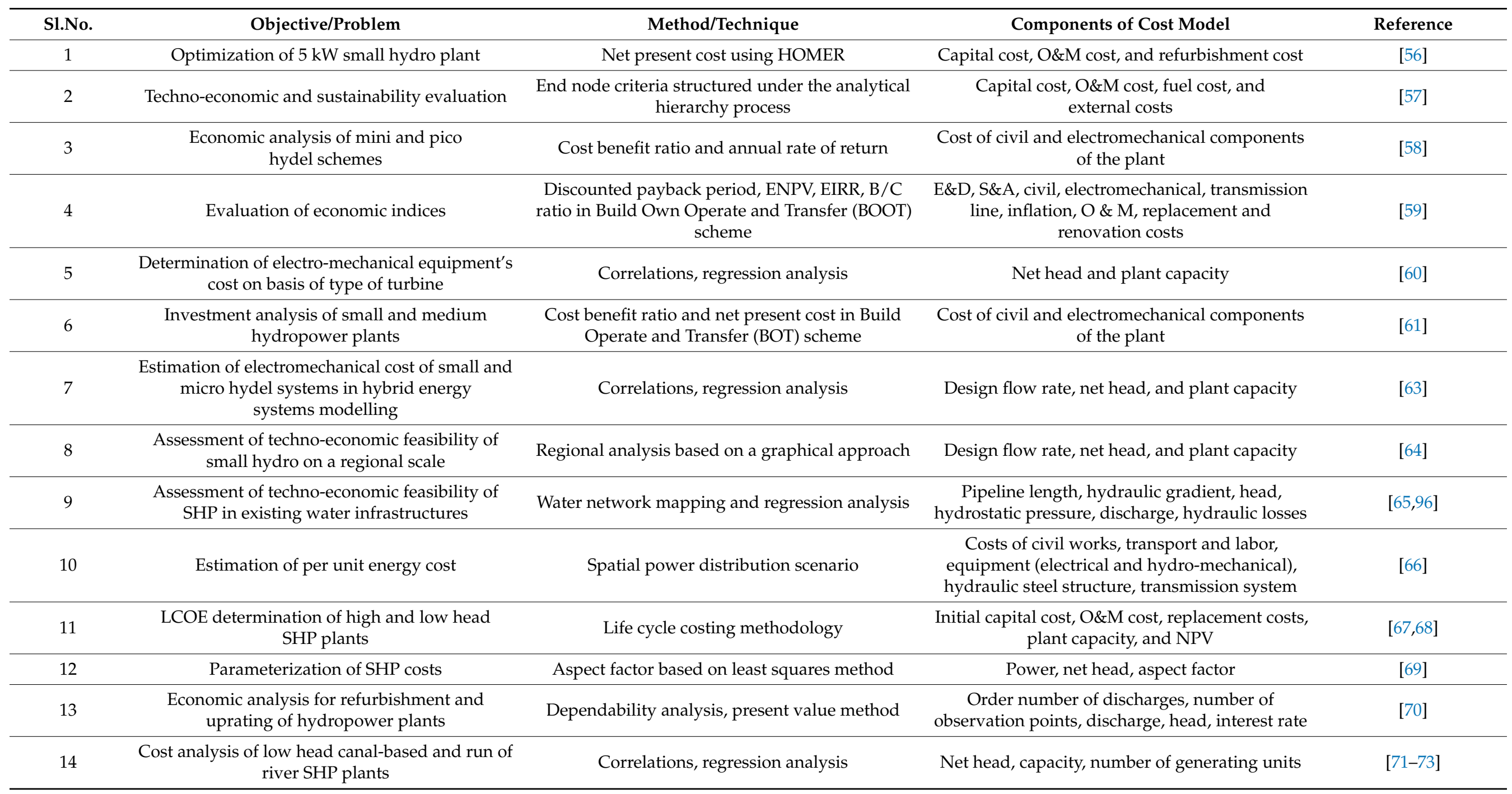


Table 5. Cont.

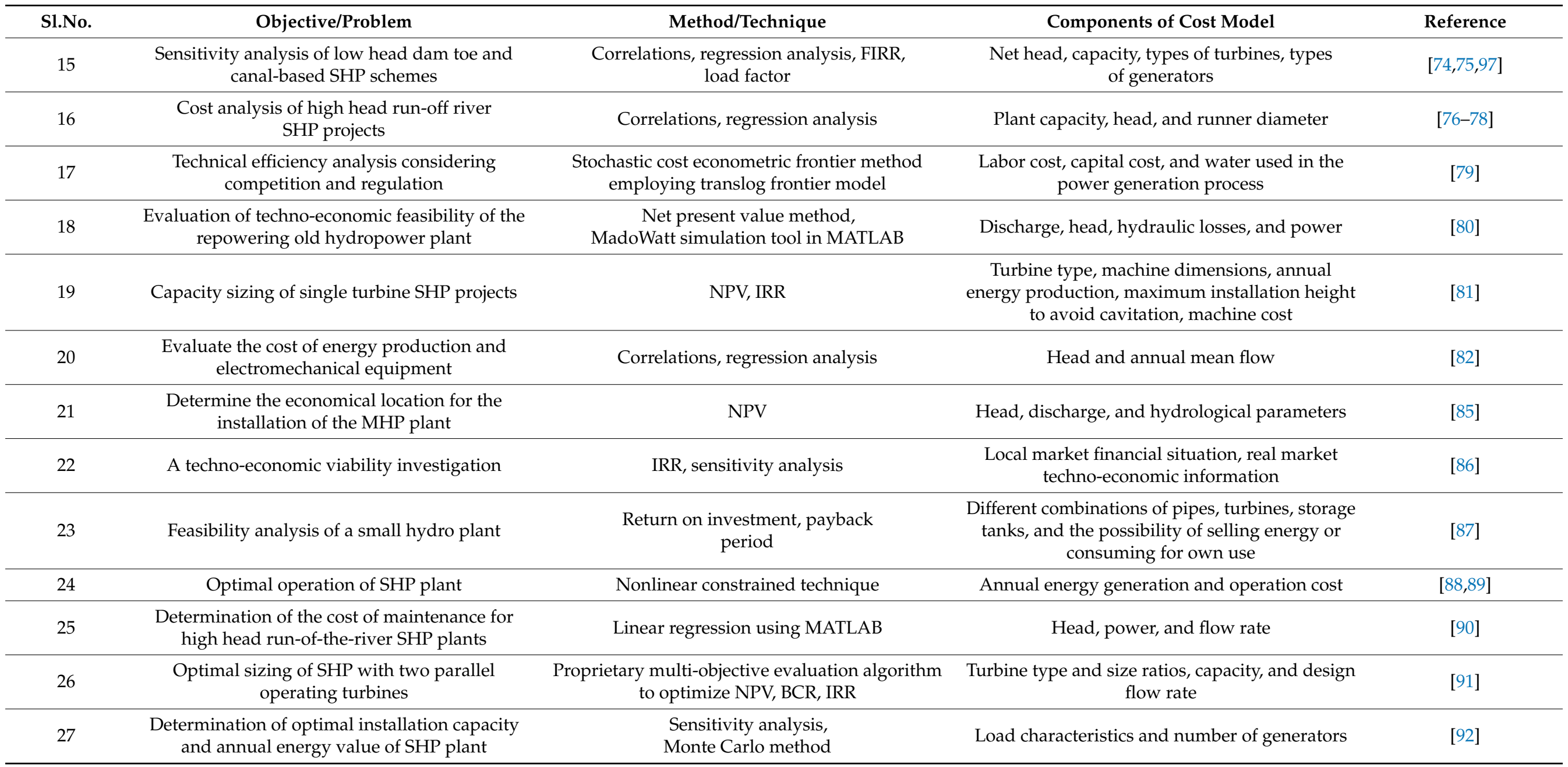




\section{Recommendations for SHP Development and Cost Reduction}

This section analyses the reasons for the low interest in the development of SHP from a financial and economic point of view. Two cases-namely, stand-alone and gridconnected SHP-are considered for this purpose. In the case of the standalone SHP, the cause of lower productivity and lower cost-benefit ratio is due to the very low utilization of electricity produced from converting the energy of water flow. Also, these plants require backup if they are to be in service which depends on the time since they do not possess a capacity feature. The backup ratio for the standalone SHP should be 100\% to have the system completely assured to zero flow conditions and the cost of such backup is generally higher. On the contrary, in a grid-connected SHP plant, demand and supply are balanced and power generation from some of the traditional generators can be decreased. In this process, they will automatically assist in the backup phenomenon which is required for the SHP schemes. The grid-connected system cost without SHP comprises capital cost, fuel cost and cost of O\&M. When SHP is integrated, the grid-connected system cost will be augmented additionally by the capital cost and the O\&M cost of the SHP generator. Alternatively, the cost of fuel for some of the traditional generators can be decreased. In the economic assessment regarding benefits and costs, the cost of environmental damages, as well as the effects of using traditional generators on the environment, needs to be properly included. Attributing the environmental damage cost to an explicit time, source, and valuing factor based on empirical evidence is challenging, as there are no market crisis currently for these factors and the problem of quantification always exists for such factors. However, environmental price is not unlimited. Establishing a price for the environment indicates restraining quantitative use for environmental indicators which can be achieved by reduction of capital cost for renewable energy generating schemes. This factor could play a decisive role in estimating the subsidy amount that could be offered for these schemes. Any scheme for SHP promotion must incentivize such that it aims at reducing the generating cost for the capital investment. Thus, the design and the role of energy/ economy interaction models are such that they investigate the effects and variations in the economy and environment in a comprehensive manner. Based on the above discussion, some of the measures proposed in the literature to improve the performance of the SHP plant and simultaneously reduce the cost of ownership are presented below.

a. The number of generators must be restricted to 2-3 to achieve economy in cost of civil works, hydro-kinetic equipment, control system redundancy, cabling, etc.

b. Rather than opting for full Kaplan, semi-Kaplan can be preferred, where the guide vanes are immovable and water flow variations can be obtained by operating the runner blades. This also helps in using a less complex version of water level controllers.

c. The span and dimension of the powerhouse can be abridged by accommodating the control panels and panels for instrumentation on the mezzanine floor, reducing the civil works cost further. Besides a simplified layout can be obtained which helps in installing the entire station in a semi-underground arrangement is feasible.

d. Capacity sizing must be sensibly done by considering all the subsystems so that the scheme will be economical.

e. With the entire accompanying subsystems, induction generator is preferred over synchronous generators in terms of economy.

f. Standardizing the design of the turbine, bearing in mind the possibility of extensive production of components and service, is essential to reduce cost. It helps to cover a range of applications with a minimum number of machine designs. The standard design of the turbine may or may not meet the specifications precisely always, but a close capacity turbine may be made available.

g. The process of standardizing must incorporate the inputs from all stakeholders aiming at a common goal of reducing the cost.

h. Replacing the guide vanes with electronic load controllers will significantly reduce the cost. 
i. The energy in low head falls of irrigation systems can be harnessed by standardizing the designs.

j. MHP schemes must be encouraged to promote the economy in rural areas by granting special subsidies and soft loans.

k. Hybridization of energy sources-i.e., development of SHP in combination with other renewables and decentralized integrated energy systems—could be promising while meeting the rural electricity demands cost-effectively.

1. There can be an increase in reliability and reduction in cost by adding storage to standalone renewable energy systems.

\section{Conclusions}

The present work attempts to review the aspects relevant to the development, and in particular the financial/cost analysis, of the SHP plants in the literature. The study examines the nitty-gritty of SHP planning and development; present status, challenges and probable solutions for the development of SHP plants; cost analysis techniques/methodologies used in SHP planning. The cost analysis procedures reviewed are useful to understand the total cost for the SHP over its lifetime, to help in proper decision making. Several strategies implemented in SHP planning and development by countries around the globe revealed that some inherent problems always exist in one or the other form. In this situation, satisfying all the constraints involved in SHP planning and development becomes a complex task. The fundamental conflict between energy, economy and environment are still persistent. A trade-off is a must between these parameters, for developing and sustainably promoting SHP plants satisfying the constraints. A sustainable solution can be obtained by a cost (financial and economic) analysis approach which analysis the cost and benefits incurring to both developer and society at large. This helps developers, policymakers, regulators, and society to analyze the advantages of developing the project and overcome any limitations hindering the development to arrive at possible solutions. The uncertainties involved in SHP planning and development becomes bigger and bigger, especially in the current age of stringent environmental regulations and power systems deregulation. Therefore, to evaluate and predict the techno-economic benefits resulting from SHP, novel comprehensive cost analysis methods need to be developed. Several technological and policy-based advancements are under development and in the planning phase for SHP projects, especially in developing and under-developed nations. Design and fabrication of savonius turbines for smaller capacity SHP project; integration of pumped hydro, SHP, solar, and wind farms for better real and reactive power control; single-window clearance system for SHP project approvals; special finance mechanisms; bridging the gap between environmentalists and project developers/enthusiasts are few such prospects which can be looked at positively for the future SHP project development.

Supplementary Materials: The following are available online at https:/ /www.mdpi.com/article/10 .3390/en14102882/s1, Table S1. Global Hydropower and SHP Statistics. Supplementary S2. Levelized cost of electricity determination (LCOE).

Author Contributions: Conceptualization, T.S.K. and E.R.P.; Methodology and formal analysis, T.S.K., E.R.P. and V.S.K.V.H.; Writing—original draft preparation, T.S.K. and E.R.P.; Writing—review and editing, T.S.K., E.R.P., V.S.K.V.H. and A.T.H.; Visualization, T.S.K. and E.R.P.; Supervision, V.S.K.V.H. and A.T.H. All authors have read and agreed to the published version of the manuscript.

Funding: This research received no external funding.

Institutional Review Board Statement: Not applicable.

Informed Consent Statement: Not applicable.

Data Availability Statement: Not applicable.

Conflicts of Interest: The authors declare no conflict of interest. 


\section{References}

1. International Energy Agency IEA. Global Energy Review 2020. Available online: https://www.iea.org/reports/global-energyreview-2020 (accessed on 31 January 2021).

2. International Energy Agency (IEA); International Renewable Energy Agency (IRENA); United Nations Statistics Division (UNSD); World Bank Group (WB); World Health Organization (WHO). Tracking SDG 7: The Energy Progress Report 2019; Washington DC. 2019. Available online: https:/ / www.irena.org/publications/2019/May/Tracking-SDG7-The-Energy-Progress-Report-2019 (accessed on 31 January 2021).

3. Kılkış, B. Accelerating the transition to $100 \%$ renewable era. But how? Exergy rationality in the built environment. In Lecture Notes in Energy; Springer: Berlin/Heidelberg, Germany, 2020; Volume 74, pp. 1-49, ISBN 978-3-030-40738-4.

4. International Energy Agency (IEA). Renewables 2020-Analysis and Forecast to 2025. Available online: https://www.iea.org/ reports / renewables-2020 (accessed on 31 January 2021).

5. REN21. Renewables 2020 Global Status Report; REN21: Paris, France, 2020; Available online: https://www.ren21.net/gsr-2020/ (accessed on 31 January 2021).

6. Gielen, D.; Boshell, F.; Saygin, D.; Bazilian, M.D.; Wagner, N.; Gorini, R. The role of renewable energy in the global energy transformation. Energy Strateg. Rev. 2019, 24, 38-50. [CrossRef]

7. United Nations Department of Economic and Social Affairs (UN DESA); United Nations Conference on Trade and Development (UNCTAD); United Nations regional commissions: Economic Commission for Africa (UNECA); Economic Commission for Europe (UNECE); Economic Commission for Latin America and the Caribbean (UNECLAC); Economic and Social Commission for Asia and the Pacific (UNESCAP); Economic and Social Commission for Western Asia (UNESCWA). World Economic Situation and Prospects 2021; Brodsky, M., Ed.; United Nations: New York, NY, USA, 2020; ISBN 9789211091823.

8. International Energy Agency IEA. World Energy Investment 2020; IEA: France, Paris, 2020.

9. Nigam, P.S. Handbook of Hydro Electric Engineering, 2nd ed.; Nem Chand \& Bros: Roorkee, India, 2008; ISBN 978-8185240961.

10. Guo, W.; Zhu, D. A review of the transient process and control for a hydropower station with a super long headrace tunnel. Energies 2018, 11, 2994. [CrossRef]

11. Qu, F.; Guo, W. Robust $H_{\infty}$ control for hydro-turbine governing system of hydropower plant with super long headrace tunnel. Int. J. Electr. Power Energy Syst. 2021, 124, 106336. [CrossRef]

12. Xu, X.; Guo, W. Chaotic behavior of turbine regulating system for hydropower station under effect of nonlinear turbine characteristics. Sustain. Energy Technol. Assess. 2021, 44, 101088. [CrossRef]

13. Danso, D.K.; François, B.; Hingray, B.; Diedhiou, A. Assessing hydropower flexibility for integrating solar and wind energy in West Africa using dynamic programming and sensitivity analysis. Illustration with the Akosombo reservoir, Ghana. J. Clean. Prod. 2021, 287, 125559. [CrossRef]

14. Liu, Y.; Guo, W. Multi-frequency dynamic performance of hydropower plant under coupling effect of power grid and turbine regulating system with surge tank. Renew. Energy 2021, 171, 557-581. [CrossRef]

15. Brown, J.G. Hydro-Electric Engineering Practice, 2nd ed.; Blackie: London, UK, 1958; Volume 1, ISBN 0216875099.

16. Nesticò, A.; Maselli, G. Estimating the declining discount rate for the economic evaluation of projects in the energy and water sectors. Adv. Sci. Technol. Innov. 2020, 17-20. [CrossRef]

17. Gupta, A.; Kumar, A.; Khatod, D.K. Optimized scheduling of hydropower with increase in solar and wind installations. Energy 2019, 183, 716-732. [CrossRef]

18. Asmelash, E.; Prakash, G.; Gorini, R.; Gielen, D. Role of IRENA for global transition to 100\% renewable energy. Lect. Notes Energy 2020, 74, 51-71. [CrossRef]

19. Liu, D.; Liu, H.; Wang, X.; Kremere, E. World Small Hydropower Development Report 2019. Available online: www. smallhydroworld.org (accessed on 31 January 2021).

20. Naidu, B.S.K. Small Hydro: Highest-Density, Nonconventional, Renewable-Energy Source, 1st ed.; National Power Training Institute: New Delhi, India, 2005. Available online: https:/ /npti.gov.in/ (accessed on 31 January 2021).

21. Fortune Business Insights. Small Hydropower Market. Size, Share and Industry Analysis By Capacity (Below 1 MW, 1-10 MW) and Regional Forecast. 2019-2026. Available online: https://www.fortunebusinessinsights.com/industry-reports/smallhydropower-market-100214 (accessed on 31 January 2021).

22. Moran, E.F.; Lopez, M.C.; Moore, N.; Müller, N.; Hyndman, D.W. Sustainable hydropower in the 21st century. Proc. Natl. Acad. Sci. USA 2018, 115, 11891-11898. [CrossRef]

23. Ritchie, H.; Roser, M. Access to Energy. Available online: https://ourworldindata.org/energy-access (accessed on 18 January 2021).

24. International Energy Agency. India 2020: Energy Policy Review. IEA 2020. Available online: www.iea.org (accessed on 31 January 2021).

25. Singh, S.; Upadhyay, M.P. Study of different issues and challanges of small hydro power plants operation. In Proceedings of the 2014 International Conference on Advances in Energy Conversion Technologies-Intelligent Energy Management: Technologies and Challenges, ICAECT, Manipal, India, 23-25 January 2014. [CrossRef]

26. UNIDO. Small Hydropower Technical Guidelines; 2019. Available online: https://www.unido.org/news/publication-smallhydropower-technical-guidelines (accessed on 31 January 2021). 
27. Department of Hydro and Renewable Energy. Standards/Manuals/Guidelines for Small Hydro Development; Roorkee. 2014. Available online: https://www.iitr.ac.in/departments/HRE/pages/Publications+Standard_and_Guidelines.html (accessed on 31 January 2021).

28. ESHA. Guide on How to Develop a Small Hydropower Plant; European Small Hydropower Association (ESHA): Brussels, Belgium, 2004; Available online: www.esha.be (accessed on 31 January 2021).

29. Alonso-Tristán, C.; González-Peña, D.; Díez-Mediavilla, M.; Rodríguez-Amigo, M.; García-Calderón, T. Small hydropower plants in Spain: A case study. Renew. Sustain. Energy Rev. 2011. [CrossRef]

30. Nautiyal, H.; Singal, S.K.; Varun; Sharma, A. Small hydropower for sustainable energy development in India. Renew. Sustain. Energy Rev. 2011, 15, 2729-2735. [CrossRef]

31. Saxena, P. Small Hydro Development In India. In Proceedings of the International Conference on Small Hydropower-Hydro Sri Lanka, Kandy, Sri Lanka, 22-24 October 2007; pp. 22-24.

32. Mishra, M.K.; Khare, N.; Agrawal, A.B. Small hydro power in India: Current status and future perspectives. Renew. Sustain. Energy Rev. 2015, 51, 101-115. [CrossRef]

33. Tsoutsos, T.; Maria, E.; Mathioudakis, V. Sustainable siting procedure of small hydroelectric plants: The Greek experience. Energy Policy 2007, 35, 2946-2959. [CrossRef]

34. Balat, H. A renewable perspective for sustainable energy development in Turkey: The case of small hydropower plants. Renew. Sustain. Energy Rev. 2007, 11, 2152-2165. [CrossRef]

35. Yüksel, I. Hydropower for sustainable water and energy development. Renew. Sustain. Energy Rev. 2010, 14, 462-469. [CrossRef]

36. Ohunakin, O.S.; Ojolo, S.J.; Ajayi, O.O. Small hydropower (SHP) development in Nigeria: An assessment. Renew. Sustain. Energy Rev. 2011, 15, 2006-2013. [CrossRef]

37. Okedu, K.E.; Uhunmwangho, R.; Odje, M. Harnessing the potential of small hydro power in Cross River state of Southern Nigeria. Sustain. Energy Technol. Assess. 2020, 37, 100617. [CrossRef]

38. Reddy, V.R.; Uitto, J.I.; Frans, D.R.; Matin, N. Achieving global environmental benefits through local development of clean energy? The case of small hilly hydel in India. Energy Policy 2006, 34, 4069-4080. [CrossRef]

39. Montes, G.M.; López, M.d.M.S.; Gámez, M.d.C.R.; Ondina, A.M. An overview of renewable energy in Spain. The small hydro-power case. Renew. Sustain. Energy Rev. 2005, 9, 521-534. [CrossRef]

40. Hicks, C. Small hydropower in China: A new record in world hydropower development. Refocus 2004, 5, 36-40. [CrossRef]

41. Adu, D.; Zhang, J.; Fang, Y.; Suoming, L.; Darko, R.O. A Case Study of Status and Potential of Small Hydro-Power Plants in Southern African Development Community. Energy Procedia 2017, 141, 352-359. [CrossRef]

42. Signe, E.B.K.; Hamandjoda, O.; Nganhou, J. Methodology of Feasibility Studies of Micro-Hydro power plants in Cameroon: Case of the Micro-hydro of KEMKEN. Energy Procedia 2017, 119, 17-28. [CrossRef]

43. Ferreira, J.H.I.; Camacho, J.R.; Malagoli, J.A.; Júnior, S.C.G. Assessment of the potential of small hydropower development in Brazil. Renew. Sustain. Energy Rev. 2016, 56, 380-387. [CrossRef]

44. Ciric, R.M. Review of techno-economic and environmental aspects of building small hydro electric plants-A case study in Serbia. Renew. Energy 2019, 140, 715-721. [CrossRef]

45. Hatata, A.Y.; El-Saadawi, M.M.; Saad, S. A feasibility study of small hydro power for selected locations in Egypt. Energy Strateg. Rev. 2019, 24, 300-313. [CrossRef]

46. Kaldellis, J.K. The contribution of small hydro power stations to the electricity generation in Greece: Technical and economic considerations. Energy Policy 2007, 35, 2187-2196. [CrossRef]

47. Manzano-Agugliaro, F.; Taher, M.; Zapata-Sierra, A.; Juaidi, A.; Montoya, F.G. An overview of research and energy evolution for small hydropower in Europe. Renew. Sustain. Energy Rev. 2017, 75, 476-489. [CrossRef]

48. Pang, M.; Zhang, L.; Bahaj, A.B.S.; Xu, K.; Hao, Y.; Wang, C. Small hydropower development in Tibet: Insight from a survey in Nagqu Prefecture. Renew. Sustain. Energy Rev. 2018, 81, 3032-3040. [CrossRef]

49. Sharma, A.K.; Thakur, N.S. Resource potential and development of small hydro power projects in Jammu and Kashmir in the western Himalayan region: India. Renew. Sustain. Energy Rev. 2015, 52, 1354-1368. [CrossRef]

50. Stevovic, S.; Milovanovic, Z.; Stamatovic, M. Sustainable model of hydro power development-Drina river case study. Renew. Sustain. Energy Rev. 2015, 50, 363-371. [CrossRef]

51. Uddin, W.; Ayesha; Zeb, K.; Haider, A.; Khan, B.; ul Islam, S.; Ishfaq, M.; Khan, I.; Adil, M.; Kim, H.J. Current and future prospects of small hydro power in Pakistan: A survey. Energy Strateg. Rev. 2019, 24, 166-177. [CrossRef]

52. Yah, N.F.; Oumer, A.N.; Idris, M.S. Small scale hydro-power as a source of renewable energy in Malaysia: A review. Renew. Sustain. Energy Rev. 2017, 72, 228-239. [CrossRef]

53. Edomah, N.; Foulds, C.; Jones, A. Influences on energy supply infrastructure: A comparison of different theoretical perspectives. Renew. Sustain. Energy Rev. 2017, 79, 765-778. [CrossRef]

54. Bhattacharyya, S.C. Economic Analysis of Energy Investments. In Energy Economics; Springer: London, UK, 2011 ; pp. 163-189. [CrossRef]

55. Edomah, N. Economics of Energy Supply. Ref. Modul. Earth Syst. Environ. Sci. 2018, 1-16. [CrossRef]

56. Abdullahi, S.A.; Folaranmi, F.; Suleiman, A.A.; Mahmud, J.O.; Dania, D.; Haruna, M.S. Optimizing the 5 KW small hydropower supply in Mada-Gudi community, Nassarawa State, Nigeria. In Proceedings of the 2017 IEEE AFRICON Science Technology Innovation for Africa, AFRICON, Cape Town, South Africa, 18-20 September 2017. [CrossRef] 
57. Chatzimouratidis, A.I.; Pilavachi, P.A. Technological, economic and sustainability evaluation of power plants using the Analytic Hierarchy Process. Energy Policy 2009, 37, 778-787. [CrossRef]

58. Adhau, S.P. Economic Analysis and Application of Small Micro/Hydro Power Plants. In Proceedings of the International Conference on Renewable Energies and Power Quality, Valencia, Spain, 15-17 April 2009. [CrossRef]

59. Dutta, R.K.; Bajracharya, T.R.; Shakya, S.R. Economic Analysis of Small Hydropower Project-A Case Study of Lower Khare Small Hydropower Project. In Proceedings of the IOE Graduate Conference, Kathmandu, Nepal, 10-11 October 2014; pp. 348-352.

60. Ogayar, B.; Vidal, P.G. Cost determination of the electro-mechanical equipment of a small hydro-power plant. Renew. Energy 2009, 34, 6-13. [CrossRef]

61. Ogayar, B.; Vidal, P.G.; Hernandez, J.C. Analysis of the cost for the refurbishment of small hydropower plants. Renew. Energy 2009, 34, 2501-2509. [CrossRef]

62. Forouzbakhsh, F.; Hosseini, S.M.H.; Vakilian, M. An approach to the investment analysis of small and medium hydro-power plants. Energy Policy 2007, 35, 1013-1024. [CrossRef]

63. Cavazzini, G.; Santolin, A.; Pavesi, G.; Ardizzon, G. Accurate estimation model for small and micro hydropower plants costs in hybrid energy systems modelling. Energy 2016, 103, 746-757. [CrossRef]

64. Carapellucci, R.; Giordano, L.; Pierguidi, F. Techno-economic evaluation of small-hydro power plants: Modelling and characterisation of the Abruzzo region in Italy. Renew. Energy 2015, 75, 395-406. [CrossRef]

65. Zema, D.A.; Nicotra, A.; Tamburino, V.; Zimbone, S.M. A simple method to evaluate the technical and economic feasibility of micro hydro power plants in existing irrigation systems. Renew. Energy 2016, 85, 498-506. [CrossRef]

66. Balkhair, K.S.; Rahman, K.U. Sustainable and economical small-scale and low-head hydropower generation: A promising alternative potential solution for energy generation at local and regional scale. Appl. Energy 2017, 188, 378-391. [CrossRef]

67. Kishore, T.S.; Koushik, S.D.; Vidyabharati, I. Life cycle costing based LCOE method for economic analysis of low head small hydro power plants in India. Water Energy Int. 2017, 59, 43-48.

68. Kishore, T.S.; Vidyabharati, I. Lcoe characterization of high head run-of-river small hydro power plants using life cycle costing methodology. Water Energy Int. 2020, 63, 42-47.

69. Filho, G.L.T.; dos Santos, I.F.S.; Barros, R.M. Cost estimate of small hydroelectric power plants based on the aspect factor. Renew. Sustain. Energy Rev. 2017, 77, 229-238. [CrossRef]

70. Rahi, O.P.; Kumar, A. Economic analysis for refurbishment and uprating of hydro power plants. Renew. Energy 2016, 86, 1197-1204. [CrossRef]

71. Singal, S.K.; Saini, R.P. Analytical approach for development of correlations for cost of canal-based SHP schemes. Renew. Energy 2008, 33, 2549-2558. [CrossRef]

72. Singal, S.K.; Saini, R.P. Analytical Approach for Cost Estimation of Low Head Small Hydro Power Schemes. In Proceedings of the International Conference on Small Hydropower-Hydro Sri Lanka, Kandy, Sri Lanka, 22-24 October 2007.

73. Singal, S.K.; Saini, R.P.; Raghuvanshi, C.S. Analysis for cost estimation of low head run-of-river small hydropower schemes. Energy Sustain. Dev. 2010, 14, 117-126. [CrossRef]

74. Singal, S.K.; Saini, R.P. Cost analysis of low-head dam-toe small hydropower plants based on number of generating units. Energy Sustain. Dev. 2008, 12, 55-60. [CrossRef]

75. Singal, S.K.; Saini, R.P.; Raghuvanshi, C.S. Optimization of low-head, dam-toe, small hydropower projects. J. Renew. Sustain. Energy 2010, 2, 043109. [CrossRef]

76. Mishra, S.; Singal, S.K.; Khatod, D.K. Cost Analysis for High Head SHP Projects. In Proceedings of the 2012 International Congress on Informatics, Environment, Energy and Applications-IEEA 2012, Singapore, 17-18 March 2012; IACSIT Press: Singapore, 2012.

77. Mishra, S.; Singal, S.K.; Khatod, D.K. Approach for Cost Determination of Electro-Mechanical Equipment in Ror Shp Projects. Smart Grid Renew. Energy 2011, 2, 63. [CrossRef]

78. Mishra, S.; Singal, S.K.; Khatod, D.K. Cost Optimization of High Head Run of River Small Hydropower Projects. In Application of Geographical Information Systems and Soft Computation Techniques in Water and Water Based Renewable Energy Problems. Water Resources Development and Management; Majumder, M., Ed.; Springer: Singapore, 2017. [CrossRef]

79. Barros, C.P.; Peypoch, N. The determinants of cost efficiency of hydroelectric generating plants: A random frontier approach. Energy Policy 2007, 35, 4463-4470. [CrossRef]

80. Gagliano, A.; Tina, G.M.; Nocera, F.; Patania, F. Technical and economic perspective for repowering of micro hydro power plants: A case study of an early XX century power plant. Energy Procedia 2014, 62, 512-521. [CrossRef]

81. Santolin, A.; Cavazzini, G.; Pavesi, G.; Ardizzon, G.; Rossetti, A. Techno-economical method for the capacity sizing of a small hydropower plant. Energy Convers. Manag. 2011, 52, 2533-2541. [CrossRef]

82. Aggidis, G.A.; Luchinskaya, E.; Rothschild, R.; Howard, D.C. The costs of small-scale hydro power production: Impact on the development of existing potential. Renew. Energy 2010, 35, 2632-2638. [CrossRef]

83. Dudhani, S.; Sinha, A.K.; Inamdar, S.S. Assessment of small hydropower potential using remote sensing data for sustainable development in India. Energy Policy 2006, 34, 3195-3205. [CrossRef]

84. Singhal, M.K.; Kumar, A. Cost benching for civil structures of micro/mini hydro electric projects located in Uttaranchal. In Proceedings of the Himalayan Small Hydro Summit, Dehradun, India, 12-13 October 2006; pp. 381-390.

85. Montanari, R. Criteria for the economic planning of a low power hydroelectric plant. Renew. Energy 2003, $28,2129-2145$. [CrossRef] 
86. Kaldellis, J.K.; Vlachou, D.S.; Korbakis, G. Techno-economic evaluation of small hydro power plants in Greece: A complete sensitivity analysis. Energy Policy 2005, 33, 1969-1985. [CrossRef]

87. Archetti, R. Micro hydroelectric power: Feasibility of a domestic plant. Procedia Eng. 2011, 21, 8-15. [CrossRef]

88. Singh, V.K.; Singal, S.K. Optimal Operation of Run of River Small Hydro Power Plant. Biophys. Econ. Resour. Qual. 2018, 3, 1-11. [CrossRef]

89. Singh, V.K.; Singal, S.K. Analysis for operation cost of run of river SHP schemes. ISH J. Hydraul. Eng. 2020, 1-6. [CrossRef]

90. Kumar, R.; Singal, S.K.; Dwivedi, G.; Shukla, A.K. Development of maintenance cost correlation for high head run of river small hydro power plant. Int. J. Ambient Energy 2020, 1-14. [CrossRef]

91. Anagnostopoulos, J.S.; Papantonis, D.E. Optimal sizing of a run-of-river small hydropower plant. Energy Convers. Manag. 2007, 48, 1663-1670. [CrossRef]

92. Hosseini, S.M.H.; Forouzbakhsh, F.; Rahimpoor, M. Determination of the optimal installation capacity of small hydro-power plants through the use of technical, economic and reliability indices. Energy Policy 2005, 33, 1948-1956. [CrossRef]

93. Nouni, M.R.; Mullick, S.C.; Kandpal, T.C. Techno-economics of micro-hydro projects for decentralized power supply in India. Energy Policy 2006, 34, 1161-1174. [CrossRef]

94. Bøckman, T.; Fleten, S.E.; Juliussen, E.; Langhammer, H.J.; Revdal, I. Investment timing and optimal capacity choice for small hydropower projects. Eur. J. Oper. Res. 2008, 190, 255-267. [CrossRef]

95. Aslan, Y.; Arslan, O.; Yasar, C. A sensitivity analysis for the design of small-scale hydropower plant: Kayabogazi case study. Renew. Energy 2008, 33, 791-801. [CrossRef]

96. Patro, E.R.; Voltz, T.J.; Kumar, A.; Grischek, T. Micro-hydropower in drinking water gravity pipelines: A case study in Uttarakhand, India. ISH J. Hydraul. Eng. 2018, 26, 332-342. [CrossRef]

97. Singal, S.K.; Saini, R.P.; Raghuvanshi, C.S. Cost Optimisation Based on Electro-Mechanical Equipment of Canal Based Low Head Small Hydropower Scheme. Open Renew. Energy J. 2008, 1. [CrossRef] 